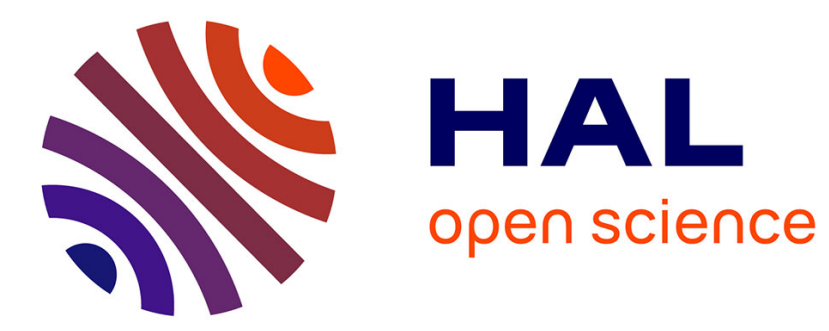

\title{
GDP-Mannose pyrophosphorylase is essential in the bloodstream form of Trypanosoma brucei
}

\author{
Helen Denton, Stewart Fyffe, Terry K Smith
}

\section{To cite this version:}

Helen Denton, Stewart Fyffe, Terry K Smith. GDP-Mannose pyrophosphorylase is essential in the bloodstream form of Trypanosoma brucei. Biochemical Journal, 2010, 425 (3), pp.603-614. 10.1042/BJ20090896 . hal-00479211

\section{HAL Id: hal-00479211 \\ https://hal.science/hal-00479211}

Submitted on 30 Apr 2010

HAL is a multi-disciplinary open access archive for the deposit and dissemination of scientific research documents, whether they are published or not. The documents may come from teaching and research institutions in France or abroad, or from public or private research centers.
L'archive ouverte pluridisciplinaire HAL, est destinée au dépôt et à la diffusion de documents scientifiques de niveau recherche, publiés ou non, émanant des établissements d'enseignement et de recherche français ou étrangers, des laboratoires publics ou privés. 


\title{
GDP-Mannose pyrophosphorylase is essential in the bloodstream form of Trypanosoma brucei.
}

\author{
Helen Denton ${ }^{\dagger}$, Stewart Fyffe \& Terry K. Smith ${ }^{\dagger *}$ \\ Biomolecular Sciences Research Complex \\ The North Haugh \\ The University \\ St. Andrews \\ Fife Scotland, U.K., KY16 9ST \\ ${ }^{\dagger}$ These authors contributed equally to this work. \\ *To whom correspondence should be addressed: \\ Tel: (0)1334-463412 \\ Fax: (0)1334-462593 \\ Email: tks1@st-andrews.ac.uk \\ Running title: GDP-Man pyrophophosphorylase in Trypanosoma brucei \\ Key words: Trypanosoma brucei / GDP-Man pyrophophosphorylase / essentiality / \\ glycosylphosphatidylinositol/ N-glycosylation / variant surface glycoprotein
}




\section{ABSTRACT}

A putative guanidine diphosphomannose pyrophophosphorylase (GDP-Man PP) gene from Trypanosoma brucei was identified in the genome and subsequently cloned, sequenced, and recombinantly expressed and shown to be a catalytically active dimer. Kinetic analysis revealed a $\mathrm{V}_{\max }$ of $0.34 \mu \mathrm{mol} / \mathrm{min} / \mathrm{mg}$ and $\mathrm{Km}$ 's of 67 $\mu \mathrm{M}$ and $12 \mu \mathrm{M}$ for GTP and mannose-1-phosphate respectively. Further kinetic studies showed GDP-Man was a potent product feedback inhibitor.

RNAi of the cytosolic TbGDP-Man PP showed mRNA levels were reduced to $\sim 20 \%$ of wild type levels, causing the cells to die after 3-4 days, demonstrating TbGDPMan PP is essential in the bloodstream form of T.brucei and thus a potential drug target. The RNAi induced parasites have a greatly reduced capability to form GDPMan, leading ultimately to a reduction in their ability to synthesize their essential glycosylphosphatidylinositol anchors. The RNAi induced parasites also showed aberrant N-glycosylation of their major cell-surface glycoprotein, variant surface glycoprotein, with loss of the high mannose Man ${ }_{9} \mathrm{GlcNAc}_{2} \mathrm{~N}$-glycosylation at Asn428 and formation of complex N-glycans at the Asn-263. 


\section{INTRODUCTION}

Eukaryotic glycosylation contains numerous examples of mannose-containing glycoconjugates i.e. protein N- and C-glycans, some O-glycans, glycosylphosphatidylinositol (GPI) anchors, as well as some glycolipid membrane anchors, and all are known to have a variety of important/essential functions [1,2].

Guanidine diphosphomannose (GDP-Man) is the critical metabolite for all mannoseglycoconjugate synthesis and is utilized directly or indirectly (via dolichol-phosphatemannose formation) as the mannose donor for all mannosylation reactions. GDP-Man pyrophosphorylase (GDP-Man PP, EC 2.7.7.13) catalyses GDP-Man formation from mannose-1-phosphate and GTP, forming the by-product pyrophosphate.

The most common form of glycosylation in eukaryotes is N-glycosylation, which utilizes both GDP-Man and dolichol-phosphate-mannose (Dol-P-Man), formed by dolichol-phosphate-mannose synthase using GDP-Man and Dol-P. Formation of the lipid linked oligosaccharide precursor ( $\mathrm{Man}_{9} \mathrm{GlcNAc}_{2}-\mathrm{PP}-\mathrm{Dol}$ ), takes place in the ER, where the first five mannoses are added to GlcNAc 2 -PP-Dol by GDP-Man dependant mannosyltransferases on the cytoplasmic face. Following flipping of the $\mathrm{Man}_{5} \mathrm{GlcNAc}_{2}$-PP-Dol intermediate the last four mannoses are added by Dol-P-Man mediated mannosyltransferases on the luminal side of the ER. The glycan portion is then transferred en bloc to Asn residues within an Asn-X-Ser/Thr sequon of a growing nascent protein [3].

Protein N-glycosylation of many membrane and secretory glycoproteins in eukaryotes serves a wide variety of functions including the promotion of correct folding, solubility, protein stabilization, endocytic sorting functions, protease resistance and signaling through interaction with lectins [3-5]. In Saccharomyces [6] and Candida [7], covalent linkage formation between cell wall proteins and glucans is mediated in part by GDP-Man PP [8]. In mycobacteria, GDP-Man PP is used to elongate the oligosaccharides of lipoglycans, lipomannan and lipoarabinomannan, potent immunomodulators in tuberculosis and leprosy [9]. Other examples of the broad biological role played by GDP-Man, include being a key intermediate in the biosynthetic pathway of ascorbic acid (Vitamin C) in plants [10,11], and the precursor for GDP-fucose synthesis $[12,13]$, used to fucosylated eukaryotic glycoconjugates, involved in a tissue development, angiogenesis, fertilization, cell adhesion, inflammation, and tumor metastasis.

In eukaryotic human pathogens, such as Leishmania, which produce large amounts of unusual Man-rich cell surface-associated and secreted glycoconjugates; $N$-glycans, GPI anchors, $O$-phosphoglycosylated proteophosphoglycans, lipophosphoglycan and glycoinositolphospholipids, the GDP-Man PP gene is a virulence factor in L.mexicana, since its deletion causes a loss of the capability to infect macrophages and mice $[14,15]$.

The closely related protozoan pathogen Trypanosoma brucei, the causative agent of African sleeping sickness, also expresses an essential glycosylated cell-surface molecule heavily dependent upon GDP-Man for its biosynthesis. Approximately $5 \mathrm{x}$ 106 dimers of the variant surface glycoprotein (VSG) are attached to the plasma membrane by a glycosylphosphatidylinositol anchor. This dense coat protects the parasite from components of the host complement system and, through antigenic variation, from specific immune responses [16-18].

Despite the variation of the VSG protein the GPI core structure attached to protein 
remains unchanged and comprises of $\mathrm{NH}_{2} \mathrm{CH}_{2} \mathrm{CH}_{2} \mathrm{PO}_{4} \mathrm{H}-6 \mathrm{Man} \alpha 1-2 \mathrm{Man} \alpha 1-6 \mathrm{Man} \alpha 1$ 4GlcNa1-6D-myo-inositol-1-HPO ${ }_{4}$-dimyristylglycerol [19]. Three distinct Dol-P-Man dependent mannosyltransferases are used in the biosynthesis of GPI anchors. The GPI biosynthetic pathway has been both genetically and chemically validated as a potential therapeutic drug target in bloodstream form T. brucei [20-22]. All variants of VSG protein are also modified with between one and three N-glycans [23]. VSG variant 221 (MiTat1.2) expressed by the cell-line used in this study, has two N-glycosylation sites: Asn-428 mostly occupied by oligomannose structures, i.e. $\mathrm{Man}_{5-9} \mathrm{GlcNAc}_{2}$, whilst the Asn-263 site is occupied by biantennary structures, i.e. $\mathrm{Man}_{3-4} \mathrm{GlcNAc}_{2}$ and GalGlcNAcMan${ }_{3} \mathrm{GlcNAc}_{2}$ [24]. Seminal work by the Ferguson group [25,26], has shown that T.brucei is unusual amongst eukaryotes, as they are able to transfer en bloc, (presumably by the different putative homologues of oligosaccharyltransferase STT3 subunits identified in the genome (Tb 927.5.890, Tb 927.5.900, Tb 927.5.910)), in a site-specific manner Man, GlcNAc2-PP-Dol for Asn428 and $\mathrm{Man}_{5} \mathrm{GlcNAc}_{2}-\mathrm{PP}-\mathrm{Dol}$ for Asn-263 of VSG221. In fact a recent paper has demonstrated that in a yeast ex vivo system, T.brucei oligosaccharyltransferase subunits are specific for transferring either biantennary or triantennary structures. [48].

In this study we characterize the recombinant T. brucei GDP-Man PP and assess the affects on having limiting amounts GDP-Man, induced by a TbGDP-Man PP RNAi cell-line on the formation of mature (N-glycosylated and GPI-anchored) VSG. 


\section{EXPERIMENTAL PROCEDURES}

Cloning of the $T$. brucei GDP-Man PP gene and formation of constructs. A putative GDP-Man PP gene was identified in the T. brucei genome database (http://www.genedb.org) [40], using tBlastN search with the $S$. cerevisiae GDP-Man PP genomic sequence as the query. The open reading frame was amplified from $T$. brucei genomic DNA using the forward and reverse primers 5'GCAGCCATATGAGGGCCGTCATTCTTGTTGGAGG-3' and 5'CCGCTCGAGCATGACCACTTCTGGTTCGGGGTGATTT-3' containing Nde1 and Xhol restriction sites respectively (underlined). A band of the expected size of ca. $1.1 \mathrm{~kb}$ was amplified using $P f u$ polymerase, purified using a QIAquick PCR purification kit (Qiagen) and cloned into pCR-Blunt II TOPO (Invitrogen) and the sequence confirmed.

The last $\sim 300 \mathrm{bp}$ of the $T b$ GDP-Man PP ORF was excised using BamHI and XhoI and ligated into the tetracycline inducible RNAi vector $\mathrm{p} 2 \mathrm{TZ}$ [41]. The sequence was confirmed and plasmid DNA was prepared using a QIAprep Miniprep Plasmid Kit (Qiagen), after digestion with NotI, it was precipitated with sodium acetate/ethanol and dissolved in sterile water to a final concentration of $1 \mu \mathrm{g} / \mu \mathrm{L}$ ready for transformation. The GDP-Man PP ORF was excised from the Tb GDP-Man PP $T O P O$ plasmid using Nde1 and Xho1 restriction sites. The product was purified using a QIAquick Gel purification kit (Qiagen) and ligated into pET20b (Novagen) vector and the sequence confirmed.

\section{Determination of native molecular mass by gel-filtration}

Gel-filtration analysis was performed using a high-resolution Sephacryl S-300 column (1.6 cm diameter, $60 \mathrm{~cm}$ long, bed volume of $120 \mathrm{ml}$ ), which was equilibrated in $20 \mathrm{mM}$ HEPES, $150 \mathrm{mM} \mathrm{NaCl}, 8 \mathrm{mM} \mathrm{MgCl}_{2}(\mathrm{pH} \mathrm{7.0})$ and run at $0.5 \mathrm{ml} / \mathrm{min}$. The column was calibrated with globular protein standards (Biorad).

\section{Expression and purification of recombinant of $T$. brucei GDP-Man PP}

The Tb GDP-Man PP pET20b construct was transformed into BL21 competent E.coli cells for expression. A single colony of freshly transformed cells was used to inoculate 200-500 $\mathrm{mL}$ of the auto-inducing media ZYP-5052 [42], containing $100 \mu \mathrm{g} / \mathrm{mL}$ ampicillin and grown at $15^{\circ} \mathrm{C}$ for 24 to $48 \mathrm{hrs}$ after which the cells were harvested by centrifugation and stored at $-20^{\circ} \mathrm{C}$. Frozen pellets were suspended in lysis buffer (20mM Tris pH 7.9, 300mM NaCl, $5 \mathrm{mM}$ imidazole) and incubated on ice with $0.2 \mathrm{mg} / \mathrm{mL}$ lysozyme (Sigma) for $30 \mathrm{~min}$. Cells were disrupted by sonication $(3 \times 30 \mathrm{sec})$ on ice and the supernatant was cleared by centrifugation $(14 / 000 \mathrm{~g}, 15 \mathrm{~min}$, $\left.4^{\circ} \mathrm{C}\right)$. Soluble GDP-Man PP was purified by batch absorption to nickel-agarose (Qiagen). Briefly, the clarified supernatant was mixed with approx. $50 \mu \mathrm{l} / \mathrm{ml}$ nickelagarose (pre-equilibrated in lysis buffer) and incubated for $1 \mathrm{~h}$ at $4^{\circ} \mathrm{C}$ with gentle mixing. The slurry and supernatant were decanted into a Poly-Prep chromatography column $(0.8 \times 4 \mathrm{~cm}$, Biorad $)$ and the packed resin was washed with lysis buffer containing $60 \mathrm{mM}$ imidazole until no protein could be detected in the outflow (approx. 5 column volumes). The bound GDP-Man PP was eluted with 1-2 ml lysis buffer containing $1 \mathrm{M}$ imidazole and was buffer exchanged into $50 \mathrm{mM}$ HEPES, 8 $\mathrm{mM} \mathrm{MgCl}$, $\mathrm{pH} 7.0$ by 3 cycles of concentration and dilution through a Vivaspin 6 spin column with a molecular weight cut off of $10 \mathrm{kDa}$ (Sartorius, Stockport, UK). The sample was adjusted to $20 \%$ glycerol and stored at $-20^{\circ} \mathrm{C}$. The purity of the recombinant GDP-Man PP was assessed by SDS-PAGE and LCT ESI-MS 
electrospray inoisation-mass spectrometry (Centre for Biomolecular Science, $\mathrm{St}$ Andrews University). Protein concentration was determined using the Bio-Rad protein assay kit using BSA as the standard.

Assay GDP-Man PP activity.

A 96-well plate assay was established for GDP-Man PP activity, based on an assay described by Davis et al. [32]. Briefly, the standard assay reaction consisted of in a final volume of $50 \mu \mathrm{l}$ : $50 \mathrm{mM}$ HEPES, $\mathrm{pH} 7.0,8 \mathrm{mM} \mathrm{MgCl}_{2}, 125 \mu \mathrm{M}$ GTP, $125 \mu \mathrm{M}$ mannose-1-phosphate, $1 \mathrm{mM}$ dithiothreotol, $0.1 \mathrm{unit} / \mathrm{ml}$ pyrophosphorylase and 0.1 $0.5 \mu \mathrm{g} G D P-M a n$ PP. The reaction was initiated by addition of enzyme or substrate and allowed to proceed for $30 \mathrm{~min}$ at $30^{\circ} \mathrm{C}$. The reaction was terminated by addition of $100 \mu$ of the detection reagent Biomol Green (Biomol Research Labs, Plymouth Meeting, PA) and the absorbance was read at $620 \mathrm{~nm}$ after further $20 \mathrm{~min}$ incubation at RT. The amount of pyrophosphate produced was estimated from a standard curve of $0-20 \mu \mathrm{M}$ sodium pyrophosphate made up in the standard assay mix.

For each assay a substrate blank and enzyme blank were carried out to account for any free phosphates already present in the sample and any non-specific activity of GDPMan PP. Specific activity is defined as units (U) per milligram of protein, where $1 \mathrm{U}$ is the amount of pyrophosphate $(\mu \mathrm{M})$ released per min at $30^{\circ} \mathrm{C}$,

\section{HPLC analysis of GDP-Man PP reaction}

The soluble reactants and products from a reaction of GTP and mannose-1-phosphate in the absence or presence of Tb GDP-ManPP, were separated using a Hypersil SAX $5 \mu$ HPLC column $(4.6 \mathrm{~mm} \times 250 \mathrm{~mm}$ Alltech), using a general method to separate nucleotides and nucleotide-phosphate sugars as described previously [43].

\section{Southern Analysis}

The GDP-Man PP ORF was PCR amplified using the same primers described above and gel purified with a QIAquick gel extraction kit (Qiagen). This fragment was then labelled with fluorescein (Gene ImagesRandom prime module, Amersham) and used for Southern blots analysis of genomic T. brucei gDNA as described previously [44].

\section{Cultivation and genetic modification of $T$. brucei}

Bloodstream form $T$. bruce i strain 427, which had been previously modified to express both $\mathrm{T} 7$ polymerase and the tetracycline repressor protein [45], are referred to here as wild-type cells for convenience. Cells were grown HMI-9 media supplemented with $\mathrm{G} 418(2.5 \mu \mathrm{g} / \mathrm{mL})$, at $37^{\circ} \mathrm{C}$ with $5 \% \mathrm{CO}_{2}$ as described elsewhere $[21,45]$.Transformation conditions and subsequent drug selection were also described elsewhere $[21,45]$. For tetracycline (a final concentration of $1 \mu \mathrm{g} / \mathrm{ml}$ ) induced RNAi experiments, cells were resuspended in the same HMI-9 media at $5 \times 10^{4}$ cells $/ \mathrm{mL}$. Cells were counted each day and were passaged only when the density was between 2 and $3 \times 10^{6}$ (normally every second day).

\section{RNA isolation and cDNA synthesis}

Total RNA was isolated from bloodstream form $T$. brucei using the RNeasy mini kit (Qiagen). TbGDP-Man PP specific cDNA was generated and amplified using the specific forward 5'- GCAGCCATATGAGGGCCGTCATTCTTGTTGGAGG -3' and reverse 5'- CCGCTCGAGTTACATGACCACTTCTGGTTCGGGGTGATTT 3' primers using the SuperScript III One step RT-PCR kit with Platinum Taq (Invitrogen). As a negative control to exclude DNA contamination of the RNA 
sample, reverse transcriptase was omitted from the reaction and replaced with GoTaq polymerase (Promega). Inositol-3-phosphate synthase (TbINO1) cDNA was also amplified using the forward and reverse primers 5'-

AGCGGCAAGCTTCTATGCCAGCCGTCCGTACGAAAA -3' and 5'CGACCTCGAGGTCAACTTCCCACGCCGCGAAGGAAAGGCAG -3' to show equal RNA input. The PCR products were then run on a $1 \%$ agarose gel.

\section{Subcellular localisation studies}

Mid-log bloodstream form cells, were harvested by centrifugation $(800 \mathrm{~g}, 10 \mathrm{~min})$ and used for either immunofluorescence or differential centrifugation. For immunofluorescence, the cells were fixed with $4 \%$ paraformaldehyde $\left(4^{\circ} \mathrm{C}\right.$, overnight). An aliquot of the fixed cells were processed as described [46], before incubation with the primary antibody; recombinant L.mexicana GDP-Man PP antirabbit antibody (kind gift from E.Handman, Melbourne), and the secondary; FITC conjugated rabbit anti-rat immunoglobulins (DakoCytomation).

For differential centrifugation, cellular fractions were prepared as described previously [46]. Proteins were separated by SDS-PAGE and transferred to ECLNylon membrane by western blotting. After blocking overnight in PBS-5\% skim milk powder, protein was detected using the primary antibody recombinant L.mexicana GDP-Man PP anti-rabbit antibody and secondary antibody; HRP conjugated rabbit anti-rat immunoglobulins (Jackson) and ECL western detection reagents.

\section{In vivo $T$. brucei metabolic labelling}

For each metabolic labelling, $2 \times 10^{7}$ mid-log cells were centrifuged $(800 \mathrm{~g}, 10 \mathrm{~min})$, washed in glucose free minimal essential media, before being resuspended in the same media at a final concentration of $1 \times 10^{7}$ cells $/ \mathrm{mL}$. Cells were labelled for $1 \mathrm{hr}$ (pulse) or $2 \mathrm{hrs}$ (pulse-chase) at $37^{\circ} \mathrm{C}$ with $50 \mu \mathrm{Ci} / \mathrm{mL}$ of either $\underline{\mathrm{D}}-\left[2-{ }^{3} \mathrm{H}\right]-$ mannose $\left(14 \mathrm{Ci} / \mathrm{mmol}\right.$, Amersham) or $\underline{\mathrm{D}}-\left[{ }^{3} \mathrm{H}\right]$-myristate $(30 \mathrm{Ci} / \mathrm{mmol}, \mathrm{ARC})$, in a shaking water bath. For pulse-chase experiments, after $1 \mathrm{hr}$ of labelling an equal volume of normal media (HMI-9) was added and the labelling allowed to continue for another hour. The cells were collected by centrifugation $(800 \mathrm{~g} 10 \mathrm{~min})$ and samples taken for either lipid or protein analysis. Lipids were extracted using chloroform:methanol:water (10:10:3 $\mathrm{v} / \mathrm{v}$ ) for $1 \mathrm{hr}$, the supernatant removed and the pellet re-extracted with chloroform:methanol $(2: 1 \mathrm{v} / \mathrm{v})$ for $1 \mathrm{hr}$. The supernantants were pooled and dried before samples were desalted using butanol/water partioning. Lipids were separated by HPTLC using silica 60 HPTLC plates and chloroform:methanol:water (10:10:3 $\mathrm{v} / \mathrm{v}$ ) as the solvent. Radio labelled lipids were detected by fluorography at $-70^{\circ} \mathrm{C}$, after spraying with $\mathrm{En}^{3}$ hance ${ }^{\mathrm{TM}}$ and using Kodak XAR-5 film with an intensifing screen. When labelling with $\left[{ }^{35} \mathrm{~S}\right]$-methionine, 1 X $10^{7}$ mid-log cells were collected by centrifugation, washed in methionine free minimal essential media and resuspended in the same media at a final concentration of $1 \times 10^{7} \mathrm{cell} / \mathrm{s} / \mathrm{ml}$. The cells were labelled for $30 \mathrm{~min}$ with $20 \mu \mathrm{Ci}\left[{ }^{35} \mathrm{~S}\right]$-methionine (MP Biomedicals, $1175 \mathrm{Ci} / \mathrm{mmol}$ ) at $37^{\circ} \mathrm{C}$. To quench the labelling, the cells were diluted in $20 \mathrm{~mL}$ of cold TDB containing $1 \mathrm{mM} \mathrm{L}$ methionine and centrifuged $\left(800 \mathrm{~g}, 10 \mathrm{~min}, 4^{\circ} \mathrm{C}\right)$. After the supernatant was removed, the cells were resuspended in TDB and an equal volume of 2X SDS-PAGE sample buffer was added prior to heating at $100^{\circ} \mathrm{C}$ for $5 \mathrm{~min}$. Proteins were separated on a $10 \%$ SDS-PAGE gel and visualised by coomassie blue staining. To detect $\left[{ }^{35} \mathrm{~S}\right]-$ labelled proteins the destained gel was soaked in $\mathrm{En}^{3}$ hance $^{\mathrm{TM}}(\mathrm{NEN})$ for $30 \mathrm{~min}$, 
washed with water twice, soaked in $10 \%$ glycerol and dried. The dried gel was then exposed to XAR-5 film overnight at $-70^{\circ} \mathrm{C}$.

\section{Isolation and enzymatic digests of sVSG}

Small scale sVSG purification and subsequent digests with either Endo-H or PNGase $\mathrm{F}$ (Calbiochem) were as performed as described previously [25].

\section{ES-MS analysis of sVSG}

sVSG obtained and purified as described above, $\sim 0.1 \mu \mathrm{g} / \mu \mathrm{L}$ of sVSG in $50 \%$ acetonitrilel, $1 \%$ formic acid was loaded into nanotips (Micromass-type F). Positiveion electrospray mass spectra on a ABI QSTAR-XL system with a tip potential of $\sim 2000 \mathrm{~V}$ and declustering potential of $60 \mathrm{~V}$ were recorded. Deconvolved data was formed using ABI Analyst software in conjunction with the Bayesian protein reconstruct program.

\section{ES-MS and ES-MS/MS analysis of glycopeptides obtained by Pronase treatment of SVSG}

Aliquots of sVSG (approximately $50 \mu \mathrm{g}$ in $150 \mu \mathrm{L}$ water) were mixed with $15 \mu \mathrm{L}$ of 1 $\mathrm{M}$ ammonium bicarbonate and $30 \mu \mathrm{L}$ of $1 \mathrm{mg} / \mathrm{mL}$ Pronase in $5 \mathrm{mM}$ calcium acetate and incubated at $37 \circ \mathrm{C}$ for $36 \mathrm{~h}$. The Pronase glycopeptides were purified/enriched using Envicarb graphitized carbon (Supelco, Poole, UK) suspended in methanol and a bed of approximately $100 \mu \mathrm{L}$ of graphitized carbon was packed into a spin column (AMBION). The columns were washed with 10 volumes of each of the following; $80 \%$ methanol, $1 \%$ formic acid; $60 \%$ methano $1,1 \%$ formic acid; and finally $1 \%$ methanol, $1 \%$ formic acid. The Pronase digest $(150 \mu \mathrm{L})$ was mixed with $850 \mu \mathrm{L}$ of $1 \%$ methanol, $1 \%$ formic acid and applied to the column 5 times. The column was washed 10 times with $100 \mu \mathrm{L}$ of $1 \%$ methanol, $1 \%$ formic acid. Glycopeptides were eluted with $100 \mu \mathrm{L}$ of $60 \%$ methanol, $1 \%$ formic acid passed through the column 10 times and concentrated. Aliquots of these samples were loaded into nanotips (Micromasstype F) and analyzed by ES-MS in positive-ion mode on an ABI Q-Star-XL instrument with tip and declustering potentials of $900 \mathrm{~V}$ and $60 \mathrm{~V}$, respectively. The product ion spectra of doubly charged species $(81 \mathrm{~m} / \mathrm{z})$ were collected using collision energies of $\sim 40 \mathrm{~V}$.

\section{Quantification of intracellular GTP and GDP-Hexose}

The method for the quantification of NTPs and NDP-sugars is an adaptation of the method of Turnock et al., [35], and will be published in full elsewhere (|Major, Fyffe and Smith unpublished). Briefly, a known number of cells were centrifuged at $800 \mathrm{~g}$ for $10 \mathrm{mins}$ at RT and washed in trypanosome dilution buffer (TDB, $5 \mathrm{mM} \mathrm{KCl}, 80$ $\mathrm{mM} \mathrm{NaCl}, 1 \mathrm{mM} \mathrm{MgSO}$, $20 \mathrm{mM} \mathrm{Na}_{2} \mathrm{HPO}_{4}, 2 \mathrm{mM} \mathrm{NaH}_{2} \mathrm{PO}_{4}, 20 \mathrm{mM}$ glucose, $\mathrm{pH} 7.7)$. The cell pellet was lysed with $100 \mu \mathrm{L}$ of cold $1 \mathrm{M}$ TCA, $150 \mathrm{pmol}$ of internal standard (2-deoxyinosine-5' triphosphate) was added to the lysate and centrifuged at $15,000 \mathrm{~g}$ for $10 \mathrm{mins}$ at $4^{\circ} \mathrm{C}$. The supernatant containing the soluble metabolites was transferred to a fresh tube prior to $25 \mu \mathrm{L}$ of $10 \mathrm{mM}$ EDTA $\mathrm{pH} 7.0$ being added, followed by $50 \mu \mathrm{L}$ chloroform and $50 \mu \mathrm{L}$ trioctylamine. The mixture was vortexed and centrifuged at $15,000 \mathrm{~g}$ for $10 \mathrm{mins}$ at $4^{\circ} \mathrm{C}$. The upper phase was carefully transferred to a fresh tube, flash frozen and freeze dried. The sample was resuspended in $60 \mu \mathrm{L}$ of $50 \%$ methanol and introduced to the mass spectrometer (Quattro Ultima Triple Quadrupole, Waters) by constant infusion at a rate of $30 \mu \mathrm{L} \mathrm{min}{ }^{-1}$. A MRM 
program was created, which specifically focussed upon a set of mass transitions. The parent ion masses of GTP, GDP-hexose and the internal standard 2-deoxyinosine-5' triphosphate were selected, and the number of ions of the principal daughter ion of each was recorded and normalised using the internal standard and standard curves. 


\section{RESULTS \& DISCUSSION}

\section{Cloning and sequencing $T$. brucei GDP-Man PP}

A putative GDP-Man PP was identified in the T. brucei genome database (Tb927.8.2050). The putative ORF was PCR amplified from Lister 427 gDNA, cloned and sequenced. The sequence has been submitted to GenBank, Accession number FM992872. An alignment of the predicted translated sequence with GDPMan PP from other organisms is shown in Figure S1.

TbGDP-Man PP shows considerable similarity to GDP-Man PP from a variety of organisms, unsurprisingly being most closely related to those from other kinetoplastids; Trypanosoma cruzi and Leishmania braziliensis. Comparative sequence analysis suggests that, like other GDP-Man PPs, the TbGDP-Man PP consists of two domains: an N-terminal nucleoside phosphate transferase domain (residues 2-235), which is highly conserved in a wide range of NTP-utilising enzymes. Also a C-terminal left-handed $\beta$-helix domain which contains several hexapeptide repeats, (residues 268-349) which is common to a number of GDP-Man PP-related enzymes and has been implicated in mediating intra-molecular associations, i.e. dimer or trimer formation [27-30]. The sequence shows no evidence of the phosphomannose isomerase motif, which is a feature of some bi-functional GDP-Man PPs found in bacteria [31].

\section{Overexpression of GDP-Man PP in E.coli}

To enable biochemical characterisation, the T. brucei GDP-Man PP was overexpressed in BL21 E. coli using a pET 20b vector, which encodes a C-terminalhexa-His tag. The His-tagged recombinant TbGDP-Man PP protein was purified using $\mathrm{Ni}^{2+}$ beads and subsequently eluted using increasing concentrations of imidazole (Figure 1A). The resultant protein was $>95 \%$ pure as assessed by SDS-PAGE (Figure $2 \mathrm{~A}$, lane 6 ) and ran with an apparent molecular weight of $\sim 42 \mathrm{kDa}$. The molecular weight of the purified recombinant protein was shown to be 41769.10 Da by LCT ESI-MS analysis, with a theoretical mass of 41769.32 Da.

The TbGDP-Man PP protein was further purified by gel-filtration (Figure 1B). Elution from the gel filtration column showed that TbGDP-Man PP (arrow) exists predominantly as a dimer in solution when compared to molecular weight standards (see arrow Figure 1C). This is distinct from the L. mexicana GDP-Man PP which has been reported to be a hexamer (a dimer of trimers) in solution [32], similar to GDPMan PP from Salmonella enterica which is a homodimer [33]. Two structural homologues of GDP-Man PP, Glmu from Streptococcus pneumoniae, and Rm1A from Pseudomonas aeruginosa, have been shown to form trimers and tetramers respectively [29,30]. Typical yields obtained were 2-4 $\mathrm{mg}$ of protein per litre of bacterial culture and $T b$ GDP-Man PP and was found to be relatively stable when stored at $-20^{\circ} \mathrm{C}$ with $20 \%$ glycerol.

\section{Activity of TbGDP-Man PP}

The purified $T b$ GDP-Man PP recombinant protein was shown to be a catalytically active by HPLC analysis (Figures 2A and 2B). This showed the conversion of GTP to the product; GDP-mannose.

Catalytic activity of GDP-Man PP was measured through the use of a coupled assay, whereby the by-product of GDP-Man PP activity, pyrophosphate, was used as a substrate for a pyrophosphatase, and the released phosphate was measured colourimetrically (Figure 2A). This is quantitative, with the amount of phosphate 
released being directly proportional to the amount of GDP-Man and pyrophosphate produced by GDP-Man PP, allowing subsequent kinetic analysis of the recombinant enzyme. Numerous controls were included to ensure that the pyrophosphatase activity was not limiting under any of the conditions used, and that no erroneous results were observed as a result of free phosphate being present in the assay prior to incubation with the pyrophosphatase. The enzyme had negligible ability to cleave phosphate from neither mannose-1-phosphate nor GTP nor other potential substrate/inhibitor (data not shown).

Like other GDP-Man PP proteins, the recombinant TbGDP-Man PP activity has a neutral $\mathrm{pH}$ optimum (Figure $\mathrm{S} 2 \mathrm{~A}$ ), all subsequent assays were carried out at $\mathrm{pH}$ 7.0. The reducing agent DTT had a slight stimulatory effect on the enzyme and was routinely included in the assay mixture at a concentration of $1 \mathrm{mM}$ (Figure S2B). The enzyme also had an absolute requirement for divalent cations, with the maximium activity obtained in the presence of $\mathrm{Mg}^{2+}(8 \mathrm{mM})$, however, this could be partially be replaced by $\mathrm{Mn}^{2+}$ and $\mathrm{Cu}^{2+}$ at certain concentrations (Figure $\mathrm{S} 2 \mathrm{C}$ ).

Kinetic parameters of $T b$ GDP-Man PP were studied, all components of the standard assay were held constant and the GTP and mannose-1-phosphate concentrations varied between 0 and $0.625 \mathrm{mM}$. The enzyme presented simple hyperbolic kinetics with respect to both substrates with a Vmax of $0.34 \pm 0.01 \mu \mathrm{mol} / \mathrm{min} / \mathrm{mg}$, with $\mathrm{Kms}$ for GTP and mannose-1-phosphate being $67 \pm 4 \mu \mathrm{M}$ and $12 \pm 1 \mu \mathrm{M}$ respectively (Figure 2C). These values are similar to the kinetic parameters reported for other GDP-Man PPs $[33,34]$. The Km of GTP is well within the observed intracellular concentration of $72 \mu \mathrm{M}$ (Major, Fyffe and Smith unpublished), implying the GDP-Man PP is working well below its Vmax.

\section{Substrate/Inhibitor Specificity}

To investigate the substrate specificity of the TbGDP-Man PP, a number of alternative nucleotide triphosphates and sugar-1-phosphates analogues up to a concentration of $1 \mathrm{mM}$ were assessed initially as potential substrates and then as potential inhibitors (Table 1). Only ATP showed appreciable activity as an alternative acceptor substrate, with hyperbolic kinetics giving a $K_{m} \sim 290 \mu \mathrm{M}$ (Table 1 and Figure S3A). None of the other NTPs including the non-hydrolysable analogues of GTP (guanosine 5'-[ $[\beta, \gamma-$ imido]triphosphate and guanosine 5 '- $[\gamma$-thio $]$ triphosphate) or other sugar1-phosphates exhibited any significant activity as inhibitors. However, as has been observed for other GDP-Man PPs [31,33], the product of the reaction GDP-mannose showed feedback inhibition, with an $\mathrm{IC}_{50}$ of $8 \pm 0.02 \mu \mathrm{M}$ (Table 1, Figure 3A). Further kinetic analysis indicated that GDP-mannose was a competitive inhibitor with respect to GTP $\left(\mathrm{k}_{\mathrm{i}} \sim 1.25 \mu \mathrm{M}\right.$ (Figures $4 \mathrm{C}$ and $\left.4 \mathrm{D}\right)$ but exhibited mixed-type inhibition with respect to mannose-1-phosphate ( $\mathrm{k}_{\mathrm{i}} \sim 2 \mu \mathrm{M}$, data not shown). This suggests the binding interaction of GDP-Man, as an inhibitor is associated primarily with the GTP binding site. The observed feedback inhibition obviously accounts for the surprisingly low steady-state intracellular GDP-Man concentration in T.brucei [35], despite it being in very high demand for N-glycosylation and GPI anchor biosynthesis.

Other GDP-Man analogues were tested as potential inhibitors, only GDP-6-deoxymannose showed any significant inhibition with an $\mathrm{IC}_{50}$ of $\sim 13 \mu \mathrm{M}$. (Table 1 , Figure 3B).

\section{GDP-Man PP is a cytosolic protein in bloodstream form $T$. brucei}

The localisation of TbGDP-Man PP was investigated in the bloodstream form of the parasite. Wild-type T. brucei cells were fixed, allowed to adhere to poly-lysine slides 
and permeablised. The GDP-Man PP protein was detected by immunofluorescence using a primary antibody against the recombinant Leishmania mexicana GDP-Man PP antibody [39], with a secondary TRITC conjugated anti-mouse, followed by counterstaining with DAPI. An even TRITC signal was observed through out the cell body, excluding the flagella, nucleus and kinetoplast, (Figure S4A-C) suggesting that TbGDP-Man PP is cytoplasmic. This result was supported by subcellular fractionation experiments followed by Western blot analysis (Figure S4D). The antiL. mexicana GDP-Man PP antibody cross-reacts with the recombinant TbGDP-Man PP (Figure S4A, lane 7) as well as detecting the GDP-Man PP from total lysates of both L. mexicana and T.brucei (Figure S4D, Lanes 1 and 6) at $\sim 45$ and $40 \mathrm{kDa}$ respectively. The antibody detected the TbGDP-Man PP primarly in the cytosolic fraction (Figure S4D, lane 5).

This cellular location is unsurprising, as the protein contains no trans-membrane domains or signal sequences for specific cellular organelles predicted from the deduced amino acid sequence. Secondly, to date all GDP-Man PP proteins isolated from tissues of various eukaryotic and prokaryotic sources have been shown to be cytosolic.

\section{GDP-Man PP is an essential gene in bloodstream form T. brucei.}

Genetic manipulations were next carried out to validate GDP-Man PP in T.brucei as a drug target. Southern blot analysis of T. brucei genomic DNA showed that GDP-Man $P P$ is present as a single copy gene per haploid genome (Figure S5A) and it is expressed both in the bloodstream and procyclic life-cycle stages. (Figure S5B). As the 'wild type' cell line used here constitutively expresses the T7 RNA polymerase and the tetracycline repressor protein, it was decided to introduce the tetracycline inducible (Ti) RNAi, p2T7 vector containing the C-terminal domain of TbGDP-Man $P P$. After drug selection with hygromycin, several clones were obtained, and the genotype of two, were confirmed by Southern blot analysis (Figure 4A, compare lane 1 with lanes 2 and 3 ).

To establish whether GDP-Man PP is an essential gene, RNAi cells at $5 \times 10^{4}$ cells $/ \mathrm{mL}$ were grown in the absence or presence of tetracycline. Cells were counted each day and split when the density was between 2 and $3 \times 10^{6}$ (normally every second day). In the absence of tetracycline, cells showed normal growth rates and morphology (Figure 4C), when compared to wild type cells (Figure 4B). However, in the presence of tetracycline $(1 \mu \mathrm{g} / \mathrm{ml}$, added daily) the RNAi cells grew normally for the first day, after which the cells either died or failed to divide (Figure 4D); these cells were swollen with multi-flagella (no specific cell-cycle arrest), until the number of live cells fell below the limits of detection by light microscopy. However, from ca. day 5-6 some live cells were visible by light microscopy, and after day 7 the cells resumed normal growth kinetics (Figure 4D). The presence of tetracycline with wildtype cells showed no detrimental growth or morphological affects, and did not affect the rate of protein synthesis (data not shown).

RT-PCR analysis (Figure 4E) showed that the transcript level of GDP-Man PP in the, RNAi cells induced for $24 \mathrm{hrs}$, had decreased significantly, $20 \%$ (Figure 4E, lane 2) compared to wild-type level (Figure 4E, lane 1). Whereas, cells which had spontaneously resumed normal growth despite the continued presence of tetracycline, for 7 days, showed wild-type levels of transcript for the GDP-Man PP (Figure 4E, lane 3). This suggests that these cells were revertants, able to break the tetracycline control, a phenomena which has been described previously for other essential genes in 
T. brucei [36, 44 and 46]. Collectively these results clearly show that GDP-Man PP is an essential gene for the viability of bloodstream form $T$. brucei.

\section{Biochemical phenotyping of the GDP-Man PP RNAi cells GDP-Man levels from wild type and RNAi GDP-Man PP cells.}

The direct effect of the RNAi knock down on GDP-Man levels in the cells was assessed using ES-MS-MS in conjuction with multiple reactant monitoring (MRM). The intracellular concentrations of GTP, GDP-Hex, and GDP-deoxy-Hex in wild-type and RNAi cells in the absence and presence of tetracycline were determined (Table S2). GDP-Hex and GDP-deoxy-Hex concentrations of $\sim 15 \mu \mathrm{M}$ and $\sim 0.5 \mu \mathrm{M}$ respectively, in both wild-type and RNAi cells in the absence of tetracycline are similar to that previously observed for bloodstream T.brucei [35], in which the authors also show that the only GDP-Hex and GDP-deoxy-Hex present in bloodstream T.brucei were GDP-Man and GDP-fucose respectively. After 24 hours of tetracycline induction of the RNAi cells, both GDP-Man and GDPfucose levels decrease significantly, to $\sim 40 \%$ and to $\sim 20 \%$ of wild-type levels, respectively (Table S1). The reduction in GDP-fucose is unsurprising as this is derived from GDP-Man via the concerted actions of the GDP-Man dehydratase (E.C. 4.2.1.47) and the GDP-fucose synthatase (E.C. 1.1.1.271).

As de novo synthesis of GDP-fucose has been shown to be essential in T.brucei, the subsequent death of the tetracycline induced GDP-Man PP RNAi cell line may due to absence of fucosylation of a yet unknown acceptor(s) [13].

Despite, the decrease in the GDP-sugars the intracellular concentration of GTP remains unchanged at $\sim 72 \mu \mathrm{M}$. This is probably unsurprising given the number, and importance of other GTP utilising enzymes, including the GTPases, i.e. Rab/Ras proteins, involved in intracellular trafficking [37]. Thus, the marginal increase due to GDP-Man PP not utilising GTP is probably insignificant, and/or GTP levels may be very tightly regulated to ensure that levels do not vary significantly.

Neither the transcript levels, nor the enzyme activity of the downstream dolicholphosphate-mannose synthase, were affected upon RNAi induction of GDP-Man PP (data not shown).

Characterisation of sVSG from wild type and RNAi GDP-Man PP induced cells. As VSG accounts for $10 \%$ of total protein synthesis and as such is the cells largest acceptor of GPI anchors and N-glycosylation, both of which are heavily dependant upon mannose activation, directly or indirectly from GDP-Man, the consequence of lower amounts $(\sim 20 \%)$ of GDP-Man induced by RNAi were assessed by investigating the maturation (glycosylation) of VSG.

Soluble form VSG glycoprotein (sVSG) was obtained by GPI-specific phospholipase C cleavage of the GPI-anchor of VSG [38] and purified from wild-type and GDPMan PP RNAi cells in the presence of tetracycline for 24 hours.

Analysis by SDS-PAGE and Coomassie blue staining showed wild-type sVSG as expected a single band (apparent $\sim 54 \mathrm{kDa}$ ) (Figure 5A, lane 1), while sVSG prepared from the GDP-Man PP RNAi induced cells appeared as a doublet, the wild type sVSG band and an additional lower sVSG band with an apparent molecular weight, $\sim 52 \mathrm{kDa}$ (Figure 5A, lane 2).

$\left[{ }^{35} \mathrm{~S}\right]-\mathrm{sVSG}$ was isolated and purified from wild-type and RNAi induced cells that were labelled with $\left[{ }^{35} \mathrm{~S}\right]$-methionine. Proteins were separated by SDS-PAGE and $\left[{ }^{35} \mathrm{~S}\right]$-labelled proteins were detected by autoradiography. The incorporation of $\left[{ }^{35} \mathrm{~S}\right]-$ methionine into the newly synthesised sVSG, shows a clear difference in migration 
between the two preparations, with the RNAi induced derived sVSG with an apparent lower molecular weight. Despite the molecular weight difference, the amount of incorporation is equal (Figure 5B compare lanes 1 and 2), showing that at the time of labelling ( 24 hours post induction) the RNAi induced cells are still fully viable and metabolically active. It should be noted that at later time points (32 and 36 hours) the cells were not viable and thus 24 hours induction was chosen at which to undertake all biochemical phenotyping.

The observed changes in the sVSG were investigated using a variety of techniques to ascertain if the molecular weight shift was due to differences in post-translational modifications, i.e. glycosylation, or in the protein. Both bands of the SVSG obtained from GDP-Man PP RNAi cells, were identified as VSG221 by mass-fingerprinting (data not shown), suggesting that the differences observed by SDS-PAGE (Figures $5 \mathrm{~A}$ and $5 \mathrm{~B}$ ) are indeed due to the difference in post-translational modifications of the same sVSG protein variant.

The glycosylation of the sVSGs were investigated using glycosidases on intact sVSG from both GDP-Man PP RNAi and wild-type cells (Figure S6, lanes 1-3 and lanes 4-6 respectively). Endo $H$ treatmentment showed a molecular weight shift for wild-type sVSG (Figure S6, compare lanes 4 and 5), with a further shift upon digesting with PNGase F (Figure S6, lane 6). This is as expected [25] as the Endo H removes the high mannose N-glycan at N-428, while the N-263 remains untouched. While the PNGase F digest removes both N-glycosylation modifications resulting in a further shift compared to that with Endo H. The Endo $H$ and PNGase F digest of the sVSG obtained from the RNAi cells showed similar shifts in molecular weight, (Figure S6, lanes 1 to 3). The PNGase F treated fully de-glycosylated sVSG coincided with that of the wild-type sVSG treated, suggesting any molecular weight differences are a result of differences in N-glycosylation, despite the modified sVSG still having an Endo $\mathrm{H}$ sensitive and an Endo $\mathrm{H}$ resistant $\mathrm{N}$-glycosylation site, like that of wild-type sVSG 221.

\section{GPI biosynthesis in wild type and RNAi induced GDP-Man PP cells.}

The affect on GPI biosynthesis was also investigated by an in vivo $\left[{ }^{3} \mathrm{H}\right]$-mannose labelling of the glycolipids. The only $\left[{ }^{3} \mathrm{H}\right]$-mannose glycolipids observed in wild-type cells were as expected mature GPI intermediates glycolipids A and C (Figure 5C, lane 3) (Smith et al., 2004). Glycolipids A and C were also observed at similar amounts in the RNAi cells in the absence of tetracycline (Figure 5C, lane 2), however after 24 hours induction the levels of both glycolipids $\mathrm{A}$ and $\mathrm{C}$ were significantly reduced ( $\sim 40 \%$, Figure $5 \mathrm{C}$, lane 1 ), however glycolipid A, the mature precursor for GPI attachment to VSG can still be seen. This suggests that at this time point (24 hours) there is still sufficient GDP-Man to make sufficient Dol-P-Man to be used by the GPI biosynthetic pathway to make sufficient mature GPI anchor for attachment to newly synthesised VSG. However, beyond this time point it is highly conceivable that this would not be the case and insufficient GPI biosynthesis for VSG maturation, subsequently leading to cell-death as previously hypothesised in the genetic and chemical validation of GPI biosynthesis in bloodstream T.brucei [20-22].

\section{Characterisation of glycopeptides from pronase digests of sVSG from wild type and RNAi induced GDP-Man PP cells.}

In order to investigate the N-glycosylation modifications further, ES-MS spectra of the intact sVSG glycoprotein were collected as described in experimental procedures. The spectrum of wild-type sVSG (Figure 6A), is similar to that described previously 
for sVSG 221 variant [25]. The observed various glycoforms as a result of structural heterogeneity at the two N-glycosylation sites [24] and in the GPI anchor [23], and are described in full in Table S2.

The sVSG spectrum of the RNAi induced cells (Figure 6B) shows two distinct envelopes of sVSG glycoforms, consistent with the two sVSG bans seen by SDSPAGE (Figure 5A). The lower molecular weight group of glycoforms has masses consistent with the C-terminal Asn-428 N-glycosylation site being unoccupied, with Asn-263 containing the basis of a complex N-glycosylation (Table S2.).

The higher molecular weight group of glycoforms, with both N-glycosylation sites occupied, with similar glycoforms to that of the wild-type sVSGs. However the distribution is different, with variations being in the N-terminal $\mathrm{N}$-glycosylation site (Table S2.).

To investigate these changes in the glycoforms of sVSG upon reduced GDP-Man levels, purified sVSG from of both wild-type and induced RNAi GDP-Man PP cells were digested with pronase. Glycopeptides, were isolated as described in experimental procedures, prior to analysis by ES-MS/MS using collison induced fragmentation of neutral loss of $81 \mathrm{~m} / \mathrm{z}$, a doubled charged loss of a terminal hexose (Figure 7). There were no observed differences in the masses of the GPI-peptide fragment between wild type and those previous characterised from sVSG variant 221 [25]. However, there were significant differences in the masses for the glycopeptides of the C-terminal (N-428) fragment, which contains the Man ${ }_{9-8} \mathrm{GlcNAc}_{2}$ glycan between the wild type and the RNAi induced cells. The absence of lower mannosylated forms at this site suggest that the reduction in GDP-Man levels does not cause immature N-glycan precursors to be transferred to the nascent chain of the newly synthesised VSG protein. If this was the case the $\mathrm{Man}_{5} \mathrm{GlcNAc}_{2}$ glycans may be seen at this position.

Instead, changes in the N-glycan attached to the N-terminal (N-263) glycosyaltion site were observed. In the wild-type SVSG the $\mathrm{Man}_{3} \mathrm{GlcNAc}_{2}$ is predominant as previously described [25]. In the RNAi induced cells this N-glycosylation site is occupied by a range of glycans including $\mathrm{Man}_{3-5} \mathrm{GlcNAc}_{2}$, with the Man 4 and $\mathrm{Man}_{5}$ species being significantly more noticeable in the sVSG obtained from the RNAi induced cells than the wild-type cells, this is mirrored by the increase in the intact sVSG glycoforms at 51022 and $51186 \mathrm{~m} / \mathrm{z}$ (Figures $6 \mathrm{~A}$ and B).

There are also other changes in the predominant species at the N-263 glycosylation site which are modified further with lactosamine groups, as depicted in Figure 7B and these are reflected in the intact sVSG glycoforms at 51058 and $51222 \mathrm{~m} / \mathrm{z}$ (Figures $6 \mathrm{~A}$ and $\mathrm{B})$.

The glycans observed for the glycoforms of sVSG that have the unoccupied Cterminal glycosylation site in the RNAi induced cells (Figure 6B, 49-50kDa), only have species with part of, or up to two lactosamine repeats at the N-terminal (N-263) glycosyaltion site. In other words there is no evidence of $\mathrm{Man}_{3-5} \mathrm{GlcNAc}_{2}$ species at this site, once the high-mannose containing glycan at the C-terminal glycosyaltion site has been lost.

Collectively, these data suggest a reduction in the amount of GDP-Man affects VSG $\mathrm{N}$-glycosylation, such that they sacrifice N-glycosylation at Asn-428 while

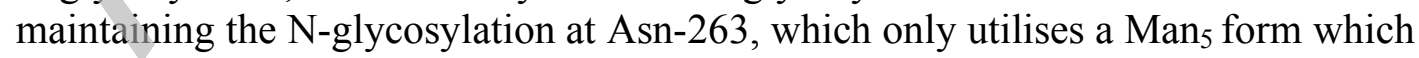
can be further processed in a site-specific manner Man ${ }_{9} \mathrm{GlcNAc}_{2}$-PP-Dol for Asn-428 and $\mathrm{Man}_{5} \mathrm{GlcNAc}_{2}$-PP-Dol for Asn-263 of VSG221 and presumably other VSG variants and may be other important glycoproteins for the parasite i.e. p67 and transferrin receptor. 
In summary, the results presented here clearly demonstrated that the viability of the bloodstream form of $T$ brucei is dependent on mannose activation, i.e. formation of GDP-Man. This dependence has been confirmed genetically by the perturbation of growth by a $T b G D P-M a n$ PP RNAi cell-line, thus validating Tb GDP-Man PP in bloodstream form $T$. brucei as a potential therapeutic drug target.

Recombinant expression and purification of catalytically active $T$. brucei GDP-Man PP protein has allowed kinetic characterisation, demonstrating product feedback inhibition and paves the way for future high-throughput screening. Indeed a competitive inhibitor of this important biosynthetic step may only have to inhibit by $\sim 80 \%$ to be lethal to the parasite, based upon the observed GDP-Man and GTP levels in the cell.

We are now actively investigating other aspects of mannose metabolism in T.brucei and related diseases for other potential drug targets, and compounds that interfere with mannose activation in a parasite specific manner. 


\section{REFERENCES}

1. Varki, A. (1999) Exploring the biological role of glycans. In: A. Varki, R. Cummings, J. Esko, H. Freeze, G. Hart and J. Marth, Editors, Essentials of Glicobiology, Cold Spring Harbor Laboratory Press, NY 57-68.

2. Ning B. and Elbein, A.D. (2000), Cloning, expression and characterization of the pig liver GDP-mannose pyrophosphorylase. Evidence that GDP-mannose and GDP-Glc pyrophosphorylases are different proteins, Eur. J. Biochem. 267, 68666874

3. Helenius A and Aebi M (2004) Roles of N-linked glycans in the endoplasmic reticulum. Annu Rev Biochem. 73, 1019-49.

4. Varki, A. (1993) Biological roles of oligosaccharides: All of theories are correct. Glycobiology 3(2): 97-130.

5. Rudd, P.M. and Dwek R.A. (1997) Glycosylation: heterogeneity and the 3D structure of proteins, Critical reviews in biochemistry and molecular biology. 32(1), 1-100.

6. Hashimoto, H., Sakakibara, A. Yamasaki, M. and Yoda, K. (1997) Saccharomyces cerevisiae VIG9 encodes GDP-mannose pyrophosphorylase, which is essential for protein glycosylation, J. Biol. Chem. 272, 16308-16314

7. Warit, S., Walmsley, R.M. and Stateva, L.I. (1998) Cloning and sequencing of the Candida albicans homologue of SRB1/PSA1/VIG9, the essential gene encoding GDP-mannose pyrophosphorylase in Saccharomyces cerevisiae, Microbiology 144, 2417-2426.

8. Warit S, Zhang N, Short A, Walmsley RM, Oliver SG, Stateva LI. (2000), Glycosylation deficiency phenotypes resulting from depletion of GDP-mannose pyrophosphorylase in two yeast species. Mol Microbiol. 36(5), 1156-66.

9. Besra, G.S., Morehouse, C.B., Rittner, C.M., Waechter, C.J. and Brennan, P.J. (1997), Biosynthesis of mycobacterial lipoarabinomannan, J. Biol. Chem. 272, 18460-18466

10. Conklin, P.L., Norris, S.R., Wheeler, G.L., Williams, E.H., Smirnoff, N. and Last, R.L. (1999) Genetic evidence for the role of GDP-mannose in plant ascorbic acid (vitamin C) biosynthesis, Proc. Nat1. Acad. Sci. U. S. A. 96, 4198-4203

11. Wheeler GL, Jones MA and Smirnoff N (1998), The biosynthetic pathway of vitamin $\mathrm{C}$ in higher plants. Nature, 393, 365-369

12. Kaufman RL and Ginsburg V (1968) The metabolism of L-fucose by HeLa cells. Exp Cell Res, 50, 127-132.

13. Turnock, D.C., Izquierdo, L. and Ferguson, M.A.J. (2007a) The de novo synthesis of GDP-fucose is essential for flagellar adhesion and cell growth in Trypanosoma brucei. J. Biol. Chem. 282, 28853-28863.

14. Garami A, Ilg T. (2001) Disruption of mannose activation in Leishmania mexicana: GDP-mannose pyrophosphorylase is required for virulence, but not for viability. EMBO J. 20(14), 3657-66.

15. Garami A, Mehlert A, Ilg T. (2001), Glycosylation defects and virulence phenotypes of Leishmania mexicana phosphomannomutase and dolicholphosphate-mannose synthase gene deletion mutants. Mol Cell Biol.; 21(23), 8168-83.

16. Cross, G.A.M. (1996) Antigenic variation in trypanosomes: secrets surface slowly. BioEssays 18, 283-287. 
17. Pays, E., L. Vanhamme \& D. Perez-Morga, (2004) Antigenic variation in Trypanosoma brucei: facts, challenges and mysteries. Curr Opin Microbiol 7, 369374.

18. Taylor, J. E. and Rudenko, G., (2006) Switching trypanosome coats: what's in the wardrobe? Trends Genet 22, 614-620.

19. Ferguson, M.A.J. (1999), The structure, biosynthesis and functions of glycosylphosphatidylinositol anchors, and the contributions of trypanosome research. J Cell Sci 112, 2799-2809.

20. Nagamune, K., Nozaki, T., Maeda, Y., Ohishi, K., Fukuma, T., Hara, T., et al. (2000) Critical roles of glycosylphosphatidylinositol for Trypanosoma brucei. Proc Natl Acad Sci USA 97, 10336-10341.

21. Chang, T., Milne, K.G., Güther, M.L.S., Smith, T.K., and Ferguson, M.A.J. (2002) Cloning of the Trypansoma brucei and Leishmania major genes encoding the GlcNAc-Phoshatidylinositol de-N-acetylase of glycosylphosphatidylinositol biosynthesis that is essential to the african sleeping sickness parasite. J Biol Chem 277, 50176-50182.

22. Smith, T.K., Crossman, A., Brimacombe, J.S., and Ferguson, M.A.J. (2004) Chemical validation of GPI biosynthesis as a drug target against African sleeping sickness. EMBO J 23, 4701-4708.

23. Mehlert, A., N. Zitzmann, J.M. Richardson, A. Treumann, and M.A. Ferguson, 1998 The glycosylation of the variant surface glycoproteins and procyclic acidic repetitive proteins of Trypanosoma brucei. Mol Biochem Parasitol. 91(1), 145-52.

24. Zamze, S.,(1991) Glycosylation in parasitic protozoa of the Trypanosomatidae family. Glycoconj. J. 8, 443-447

25. Jones, D.C., Mehlert, A.M., Güther, M.L., and Ferguson, M.A.J. (2005) Deletion of the glucosidase II gene in Trypanosoma brucei reveals novel $\mathrm{N}$-glycosylation mechanisms in the biosynthesis of variant surface glycoprotein. J Biol Chem 280, 35929-35942.

26. Manthri, S., Güther, M.L.S., Izquierdo, L., Acosta-Serrano, A. and Ferguson, M.A. J (2008) Deletion of the TbALG3 gene demonstrates novel mechanisms of N-glycosylation in Trypanosoma brucei. Glycobiology, 18, 367-383.

27. Marchler-Bauer A, Anderson JB, Derbyshire MK, DeWeese-Scott C, Gonzales NR, Gwadz M, Hao L, He S, Hurwitz DI, Jackson JD, Ke Z, Krylov D, Lanczycki CJ, Liebert CA, Liu C, Lu F, Lu S, Marchler GH, Mullokandov M, Song JS, Thanki N, Yamashita RA, Yin JJ, Zhang D, Bryant SH. (2007) CDD: a conserved domain database for interactive domain family analysis. Nucleic Acids Res. 35, D237-40

28. Perugini MA, Griffin MD, Smith BJ, Webb LE, Davis AJ, Handman E, Gerrard JA. (2005), Insight into the self-association of key enzymes from pathogenic species. Eur Biophys J. 34(5), 469-76.

29. Sulzenbacher G, Gal L, Peneff C, Fassy F, Bourne Y.(2001) Crystal structure of Streptococcus pneumoniae N-acetylglucosamine-1-phosphate uridyltransferase bound to acetyl-coenzyme A reveals a novel active site architecture. J Biol Chem. 276, 11844-51

30. Blankenfeldt W, Asuncion M, Lam JS, Naismith JH (2000) The structural basis of the catalytic mechanism and regulation of glucose-1-phosphate thymidylyltransferase (RmlA). EMBO J. 19, 6652-63.

31. Wu, B., Zhang, Y., Zheng, R., Guo, C. and P.G. Wang (2002) Bifunctional phosphomannose isomerase/GDP--mannose pyrophosphorylase is the point of control for GDP--mannose biosynthesis in Helicobacter pylori. FEBS Letters, 
519(1-3), 87-92.

32. Davis AJ, Perugini MA, Smith BJ, Stewart JD, Ilg T, Hodder AN, Handman E. (2004), Properties of GDP-mannose pyrophosphorylase, a critical enzyme and drug target in Leishmania mexicana. J Biol Chem. 279(13):12462-8.

33. Elling, L., Ritter, J.E. and Verseck, S. (1996) Expression, purification and characterisation of recombinant phosphomannomutase and GDP- $\alpha$-D-mannose pyrophosphorylase from Salmonella enterica, group B, for the synthesis of GDP$\alpha$-D-mannose from D-mannose. Glycobiology , 591-597

34. Watt, G.M., Flitsch, S.L., Fey, S., Elling, L. and Kragl, U. (2000), The preparation of deoxy derivatives of mannose 1-phosphate and their substrate specificity towards recombinant GDP-mannose pyrophosphorylase from Salmonella enteric, group B. Tetrahydron 11, 621-628

35. Turnock, D.C. and Ferguson, M.A.J. (2007) The sugar nucleotide pools of Trypanosoma brucei, Trypanosoma cruzi and Leishmania major. Eukaryotic Cell 6, 1450-1463.

36. Roper, J.R., Guther, M.L.S., Milne, K.G., and Ferguson, M.A.J. (2002) Galactose metabolism is essential for the African sleeping sickness parasite Trypanosoma brucei. Proc Natl Acad Sci USA 99, 5884-5889.

37. Field, M.C., Natesan, S., Gabernet-Castello, C., and Koumandou, V.L. (2007) Intracellular trafficking in trypanosomes. Traffic 8, 629-639

38. Cross GA. (1984) Structure of the variant glycoproteins and surface coat of Trypanosoma brucei. Philos Trans R Soc Lond B Biol Sci 307(1131), 3-12

39. Stewart, J., Curtis, J., Spurk, T.P., Ilg, T., Garami, A., Baldwin, T., Courret, N., McFadden, G.I., Davis, A., and Handman, E. (2005) Characterisation of a Leishmania mexicana knockout lacking guanosine diphosphate-mannose pyrophosphorylase. Int J Parasitol. 35(8), 861-73.

40. Berriman, M., Ghedin, E., Hertz-Fowler, C., Blandin, G., Renauld, H., Bartholomeu, D.C. et al. (2005), The genome of the African trypanosome Trypanosoma brucei. Science 309, 416-422

41. Alibu, V.P., L. Storm, S. Haile, C. Clayton, and D. Horn, (2005) A doubly inducible system for RNA interference and rapid RNAi plasmid construction in Trypanosoma brucei. Mol Biochem Parasitol. 139(1), 75-82.

42. Studier, F.W. (2005) Protein production by auto-induction in high density shaking cultures. Protein Expr Purif 41, 207-234

43. Schneider, P., McConville, M.J. and Ferguson, M.A.J. (1995) Characterization of GDP- $\alpha$-D-arabinopyranose, the precursor of D-Arap in Leishmania major lipophosphoglycan. J. Biol. Chem. 269, 18332-18337.

44. Martin, K.L., and Smith, T.K. (2006) Phosphatidylinositol synthesis is essential in bloodstream form Trypanosoma brucei. Biochem J 396, 287-295

45. Wirtz, E., Leal, S., Ochatt, C. and Cross, G. A. M. (1999), A tightly regulated inducible expression system for conditional gene knock-outs and dominantnegative genetics in Trypanosoma brucei. Mol Biochem Parasitol 99, 89-101

46. Martin, K.L., and Smith, T.K. (2006b) The glycosylphosphatidylinositol (GPI) biosynthetic pathway of bloodstream-form Trypanosoma brucei is dependent on the de novo synthesis of inositol. Mol Microbiol 61, 89-105

47. Ariyanayagam, M.R., Oza, S.L., Guther, M.L. and Fairlamb, A.H. (2005) Phenotypic analysis of trypanothione synthetase knockdown in the African trypanosome Biochem J 391,425-432

48. Izquierdo, L., Schulz, B.L., Rodrigues, J.A., Guther, M.L, Procter, J.B., Barton, G.J., 
Abei, M. and Ferguson, M.A.J. (2009) Distinct donor and acceptor specificities of Trypanosoma brucei oligosaccharyltransferases. EMBO J 28, 2650-2661.

\title{
ACKNOWLEDGEMENTS
}

This work was supported by a Wellcome Trust Senior Resarch Fellowship; 067441. We wish to thank E.Handman, Melbourne for the generous gift of Leishmania mexicana GDP-Man PP antibody. We wish to thank Paul Appleton (School of Life Sciences, Univ of Dundee) for taking the immunofluroresence images. We wish to thank Prof Ralph Schwarz for access to non-commercial GDP-Man analogues.

We wish to thank for access to mass spectrometry facilities at both Dundee and St Andrew Universitys.

\section{FOOTNOTES}

The nucleotide sequence(s) reported in this paper has been submitted to the GenBankTM/EBI Data Bank with accession number FM992872.

\begin{abstract}
ABBREVIATIONS
The abbreviations used are: GDP-Man, guanidine diphosphomannose; GDP-Man PP, guanidine diphosphomannose pyrophophosphorylase; Dol-P-Man, dolicholphosphate-mannose; DAPI, 4',6-diamidino-2-phenylindole; DTT, dithiothreitol; ESIMS/MS, electrospray ionisation tandem mass spectrometry; MRM, multiple reactant monitoring; FITC, fluorescein 5'-isothiocyanate; GPI, glycosylphosphatidylinositol;; HA, hemagglutinin; HPTLC, high performance thin layer chromatography; HYG, hygromycin phosphotransferase; ORF, open reading frame; TDB, trypanosome dilution buffer; Ti, tetracycline-inducible.
\end{abstract}




\section{FIGURE LEGENDS}

Figure 1. Expression and purification of recombinant $\boldsymbol{T b G D P - M a n ~ P P .}$ (A) TbGDP-Man PP was cloned into the expression vector $\mathrm{pET} 20 \mathrm{~b}$ (C-terminal Hexa-His tag) and transformed into BL21 competent cells, and grown in autoinduction media and purified as described in experimental procedures. TbGDPMan PP protein samples from each purification step were separated on a $10 \%$ SDSPAGE gel and stained with Coomassie brilliant blue. Lane 1, total protein after induction; Lane 2, insoluble protein; Lane 3, cleared lysate; Lane 4, unbound to $\mathrm{Ni}^{2+}$ column; Lane 5, elution from $\mathrm{Ni}^{2+}$ column at $60 \mathrm{mM}$ imidazole; Lane 6, elution from the nickel column at $1 \mathrm{M}$ imidazole.

(B) Gel-filtration analysis of TbGDP-Man PP. Purified recombinant TbGDP-Man PP was passed through a high-resolution Sephacryl S-300 column. Absorbance at 280nm was monitored against elution volume. The column was calibrated with globular protein standards (Biorad).

(C) Determination of native molecular mass by gel-filtration.

Tb GDP-Man PP elution from the gel filtration column indicates Tb GDP-Man PP is present primarily as a dimmer (arrow).

\section{Figure 2. Kinetic Analysis of GDP-Man formation by TbGDP-Man PP}

(A) Reaction catalysed by GDP-Man PP. The enzyme GDP-Man PP uses GTP and mannose-1-phosphate to form GDP-Man. The rate of reaction is monitored by pyrophosphorylase formation of phosphate from the pyrophosphate by-product. (B) TbGDP-Man PP catalyses the formation of GDP-Man. The substrate GTP and the product of the reaction GDP-Man, were separated by HPLC as described in experimental procedures.

(C) Kinetics analysis of recombinant TbGDP-Man PP

Enzyme activity was measured as described in experimental procedures, data are presented as mean \pm SD from three measurements. Determination of MichaelisMenten constants for mannose-1-phosphate and GTP GTP concentration was held constant $(125 \mu \mathrm{M})$ while mannose-1-phosphate concentration was varied. Mannose-1phosphate concentration was held constant $(125 \mu \mathrm{M})$ while GTP concentration was varied. Insert shows Lineweaver-Burk plot of data.

\section{Figure 3. Kinetic analysis of feedback inhibition of TbGDP-Mann PP}

(A) $\mathrm{IC}_{50}$ curve for the inhibition of TbGDP-Man PP by GDP-mannose, the calculated $\mathrm{IC}_{50}$ is $8 \pm 1 \mu \mathrm{M}(n=3)$. (B) $\mathrm{IC}_{50}$ curve for the inhibition of TbGDP-Man PP by GDP6 deoxy-mannose, calculated $\mathrm{IC}_{50} \sim 13 \mu \mathrm{M}(n=2)$. (C) GTP saturation curves of TbGDP-Man PP showing competitive inhibition by varying concentrations of GDPmannose ( $(, 0 \mu \mathrm{M}$ GDP-mannose, $\bullet, 1.525 \mu \mathrm{M}$ GDP-mannose $\square, 3.125 \mu \mathrm{M}$ GDPmannose $\boldsymbol{n}, 6.25 \mu \mathrm{M}$ GDP-mannose $\Delta, 12.5 \mu \mathrm{M}$ GDP-mannose $\boldsymbol{\Delta}, 25 \mu \mathrm{M}$ GDPmannose). (D) Dixon plot of data from (C) (०, $9.7 \mu \mathrm{M}$ GTP, •, $19.5 \mu \mathrm{M}$ GTP, $\square, 39$ $\mu \mathrm{M}$ GTP,$-78 \mu \mathrm{M}$ GTP $, \Delta, 156 \mu \mathrm{M}$ GTP $\boldsymbol{\Delta}, 312.5 \mu \mathrm{M}$ GTP) The $\mathrm{K}_{\mathrm{i}}$, estimated from the intersection point, is approximately $1.25 \mu \mathrm{M}$. All assays were carried out under standard conditions using a fixed quantity of purified TbGDP-Man PP and varying concentrations of inhibitor or GTP.

Figure 4. Construction of Tb GDP-Man PP RNAi cell line.

(A) Confirmation of genotype of T. brucei GDP-Man PP RNAi cell line. Southern blot analysis of digested genomic DNA (ca. $2 \mu \mathrm{g}$ ) from wild type T. brucei cells (Lane 
1) and 2 different clones of P2T7-GDP-Man PP (Lanes 2 and 3), the GDP-Man PP ORF probe shows allelic TbGDP-Man $P P$ at $5 \mathrm{~kb}$ and the P2T7 copy lower at ca. $4 \mathrm{~kb}$. (B-D) Growth curves of either (B), wild type or Tb GDP-Man PP RNAi cells grown in the presence $(C)$ or absence (D) of tetracycline $(1 \mathrm{mg} / \mathrm{ml})$, and counted daily. (E) RT-PCR amplification of GDP-Man PP RNA transcripts from total RNA extracted from TbGDP-Man PP RNAi cell line grown in the absence of tetracycline for 0,24 hours and 8 days (lanes 1,2 and 3 respectively). The upper panel shows RTPCR products using primers specific for TbGDP-Man PP; the lower panel shows a loading control using inositol-3-phosphate synthetase (TbINO1) primers as detailed in experimental procedures.

\section{Figure 5: Biochemical phenotyping of SDS-PAGE of Tb GDP-Man PP RNAi cell} lines.

A) Soluble form VSG (sVSG) variant 221 was purified from wild-type cells (lane 1) and Tb GDP-Man PP RNAi cell induced with tetracycline for 24 hours (lane 2), were purifed as described in experimental procedures and analysed by SDS-PAGE stained with Coomassie. The position of a modified sVSG221 with an apparent lower molecular weight than wild type sVSG is indicated on the right hand side.

(B) Wild-type cells (lane 1) and Tb GDP-Man PP RNAi cell induced with tetracycline for 24hours (lane 2) were labelled with $\left[{ }^{35} \mathrm{~S}\right]$-methionine for one hour. Soluble form VSG221s were purified from the two cell types and separated on an SDS-PAGE gel and detected by fluorography. The corresponding Coomassie stained gel (lanes 3 and 4). Molecular weight standard is indicated on left

(C) Analysis of the affect of Tb GDP-Man PP RNAi on the GPI pathway. Wild-type cells (lane 3) and Tb GDP-Man PP RNAi cells in the absence (lane 2) or presence of tetracycline for 24 hours (lane 1) were then for 60 min with $\left[{ }^{3} \mathrm{H}\right] \mathrm{Man}$ as described in experimental procedures. Extracted glycolipids were analysed by HPTLC and fluorography. The two mature GPI anchor intermediates are indicated as glycolipid A, EtN $P-\mathrm{Man}_{3} \mathrm{GlcN} \alpha 1-6 \mathrm{PI}$ and glycolipid C, EtN $P-\mathrm{Man}_{3} \mathrm{GlcN} \alpha 1-6(2-\mathrm{O}-$ acyl)PI.

\section{Figure 6: ES-MS analysis of $\mathrm{s} V \mathrm{SG}$ glycoforms.}

Samples of sVSG from wild-type (A) and Tb GDP-Man PP RNAi cells induced with tetracycline for 24hours (B) were analysed by positive ion ES-MS and as described in experimental procedures. The major glycoform is depicted in panel A, while the changes observed under permissive conditions of RNAi are highlighted along with the glycoforms at the N-terminal N-glycosylation site. Supplmentary Table 2 shows the composition of all of the glycoforms observed both in A and B. The glycan structures are represented by filled boxes for GlcNAc residues, filled circles for Man residues, empty circles for Gal residues and empty boxes for GlcN residues.

Figure 7: Mass spec analysis of glycopeptides released by pronase digested sVSG221.

Purified sVSG221 from wild-type cells (A) and Tb GDP-Man PP RNAi cell induced with tetracycline for 24 hours $(\mathrm{B})$ were digested with pronase and enriched using Envib-carb, prior to analysis by ES-MS and ES-MS-MS, as described in experimental procedures.

The identities of the indicated glycopeptide ions were confirmed by ES-MS/MS. The $\mathrm{m} / \mathrm{z}$ values of the parent ions and the product ion spectra are consistent with previous assignments (Jones et al., 2005); $m / z 703\left[\mathrm{Man}_{3} \mathrm{GlcNAc}_{2}-\mathrm{NETAG}+\mathrm{H}+\mathrm{Na}\right]^{2+} ; \mathrm{m} / \mathrm{z}$ 
$729\left[\mathrm{GlcNAcMan}_{3} \mathrm{GlcNAc}_{2}-\mathrm{NET}+2 \mathrm{H}\right]^{2+} ; m / z 874\left[\mathrm{GPI}(\mathrm{Gal})_{4}+2 \mathrm{H}\right]^{2+} ; \mathrm{m} / z 956$ $\left[\mathrm{GPI}(\mathrm{Gal})_{5}+2 \mathrm{H}\right]^{2+} ; m / z 1037\left[\mathrm{GPI}(\mathrm{Gal})_{6}+2 \mathrm{H}\right]^{2+} ; m / z 1,156\left[\mathrm{Man}_{8} \mathrm{GlcNAc}_{2-}\right.$ $\mathrm{GNTNTT}+\mathrm{H}+\mathrm{Na}]^{2+} ; m / z$ 1,236 [Man$\left.{ }_{9} \mathrm{GlcNAc}_{2}-\mathrm{GNTNTT}+\mathrm{H}+\mathrm{Na}\right]^{2+}$. Ser-GPI represents serine-ethanolaminephosphate-6Man 1 1-2Man $\alpha 1-6 \mathrm{Man} \alpha 1$ 4GlcNa1-6-D-myo-inositol-1,2-cyclic phosphate and NETAG, NET, and GNTNTT are single-letter amino acid sequences for the $\mathrm{N}$ - and $\mathrm{C}$-terminal $\mathrm{N}$-glycosylation sites, N-263 and N-428 respectively. The glycopeptide structures are represented by filled boxes for GlcNAc residues, filled circles for Man residues, empty circles for Gal residues and empty boxes for GlcN residues. 
Table 1: Kinetic analysis of potential substrate/inhibitors of T.brucei GDP-Man PP

\begin{tabular}{|c|c|c|}
\hline Analogue & Substrate & Inhibitor \\
\hline GTP & $\begin{array}{l}\mathrm{Km} 67 \pm 4 \mu \mathrm{M} \\
\text { (see Fig } 3 \mathrm{C} \text { ) }\end{array}$ & $\mathrm{N} / \mathrm{A}$ \\
\hline UTP & Very weak $^{\mathrm{a}}$ & Very weak \\
\hline CTP & Very weak & $\mathrm{IC} 50>625 \mu \mathrm{M}$ \\
\hline ATP & $\begin{array}{c}\mathrm{Km} 290 \mu \mathrm{M} \\
\text { (see SupFig 2) }\end{array}$ & $\mathrm{IC} 50>625 \mu \mathrm{M}$ \\
\hline G- $\gamma$-imido-TP & N/A & $\mathrm{No}^{b}$ \\
\hline G- $\gamma$-thio-TP & N/A & No \\
\hline GDP & No & Very weak $^{\mathrm{a}}$ \\
\hline GMP & No & No \\
\hline Man-1-P & $\begin{array}{l}\mathrm{Km} 12 \pm 1 \mu \mathrm{M} \\
\text { (see Fig } 3 \mathrm{C} \text { ) }\end{array}$ & $\mathrm{N} / \mathrm{A}$ \\
\hline Glc-1-P & No & No \\
\hline Gal-1-P & No & No \\
\hline Fuc-1-P & Very weak & No \\
\hline Ino-1-P & No & No \\
\hline GDP-Man & $\mathrm{N} / \mathrm{A}$ & $\begin{array}{l}\text { IC50 } 8 \pm 0.2 \mu \mathrm{M} \\
(\text { see Fig } 4 \mathrm{~A})\end{array}$ \\
\hline GDP-Glc & $\mathrm{N} / \mathrm{A}$ & \\
\hline GDP-Fuc & $\mathrm{N} / \mathrm{A}$ & Very weak \\
\hline GDP-3-d-Man & & No \\
\hline GDP-4-d-Man & $\mathrm{N} / \mathrm{A}$ & No \\
\hline GDP-6-d-Man & $\mathrm{N} / \mathrm{A}$ & $\begin{array}{l}\text { IC50 13 } 4 \mathrm{M} \\
\text { (see Fig 4B) }\end{array}$ \\
\hline
\end{tabular}

${ }^{\text {a }}$ Very weak - weak substrate or inhibitor (less than $10 \%$ inhibition) at $1 \mathrm{mM}$.

${ }^{\mathrm{b}}$ No observed activity as substrate or activity at $1 \mathrm{mM}$.

G- $\gamma$-imido-TP -Guanosine 5' -[ $\beta, \gamma$-imido]triphosphate

G- $\gamma$-thio-TP -Guanosine 5'-[ $\gamma$-thio]triphosphate 
Figure 1

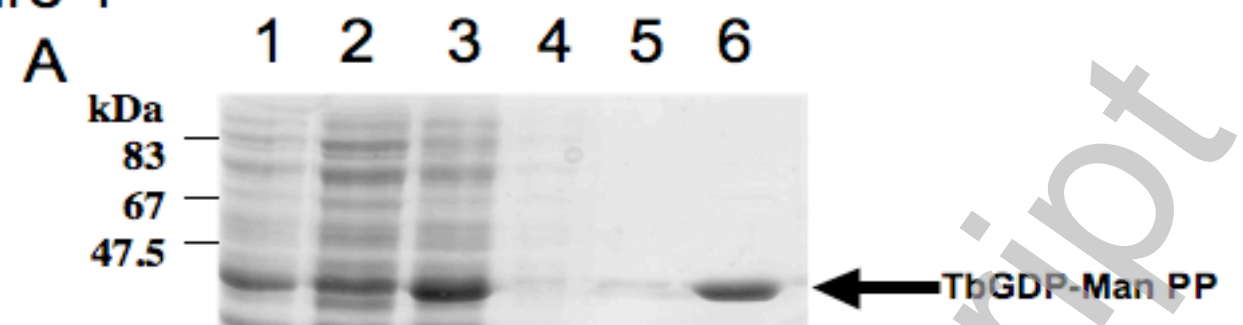

$32.5^{-}$

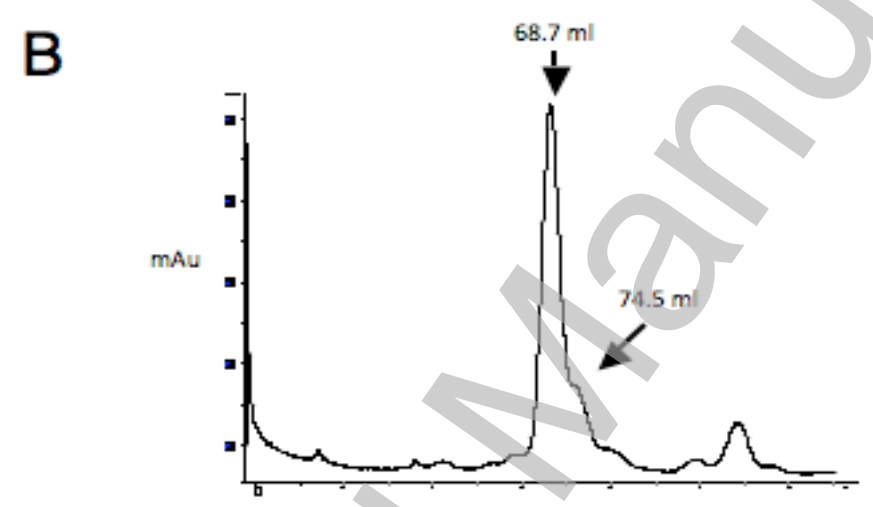

C Elution volume (ml)

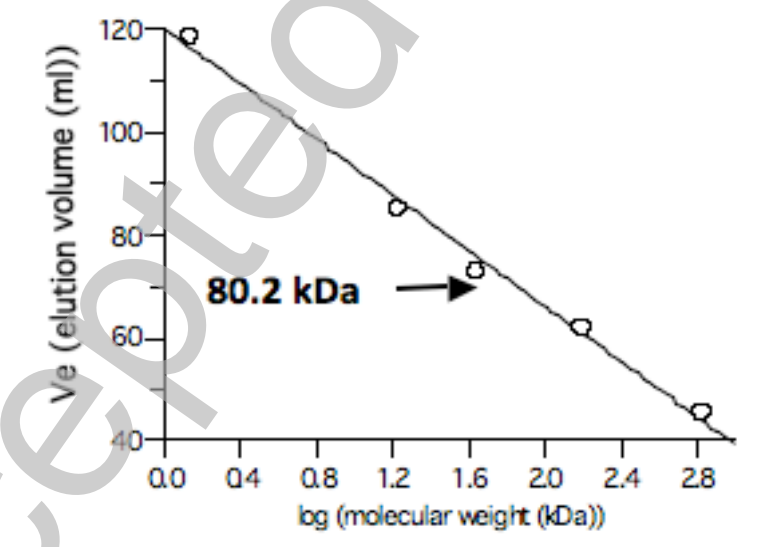




\section{Figure 2}

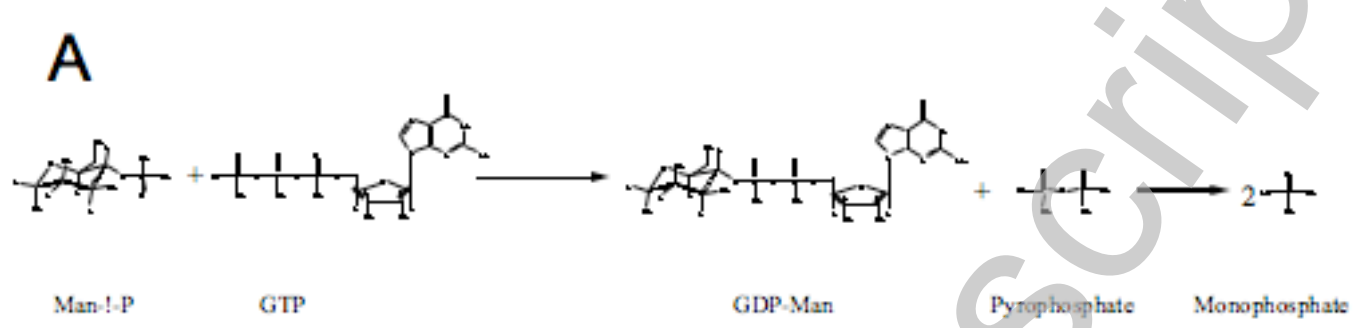

B
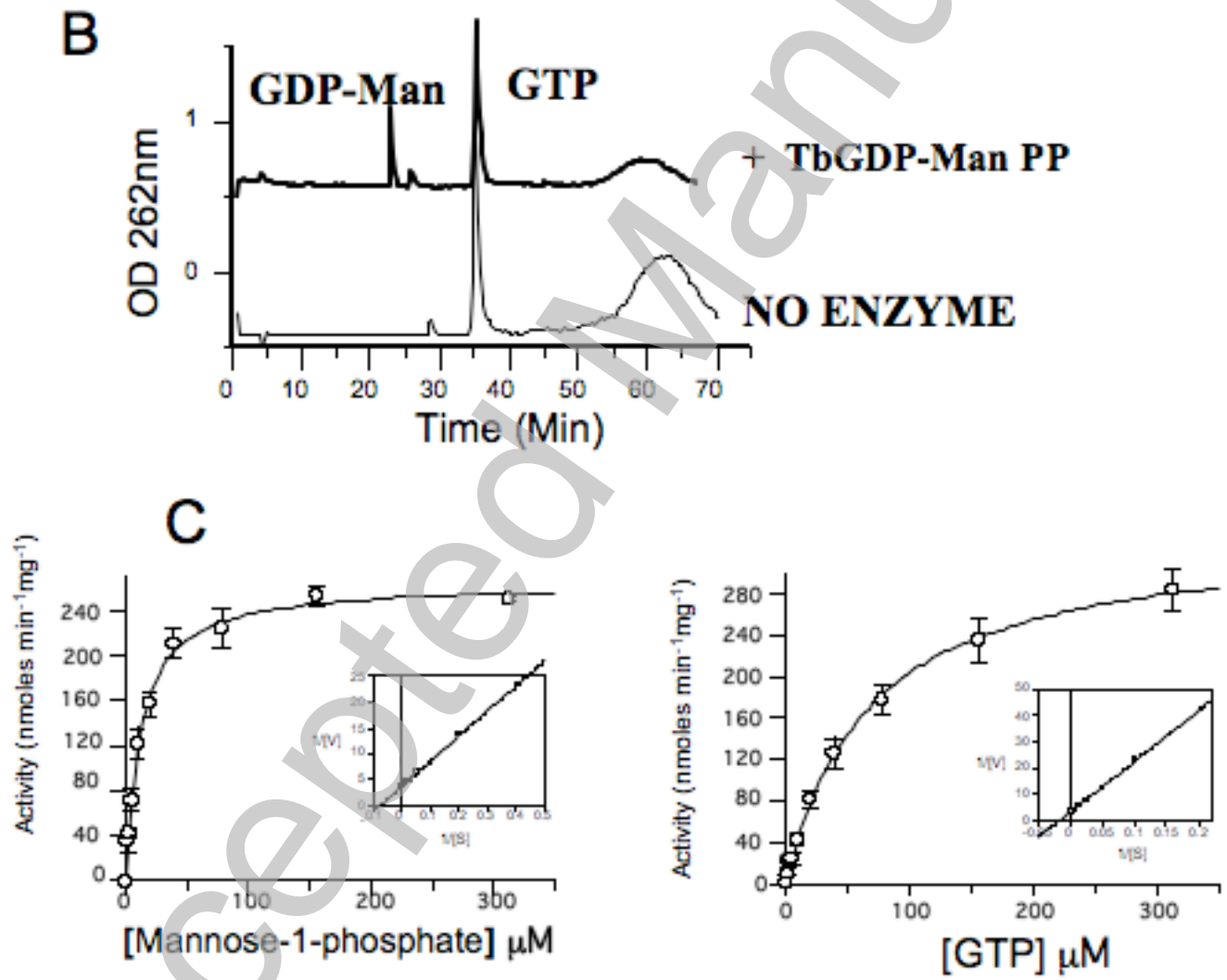


\section{Figure 3}
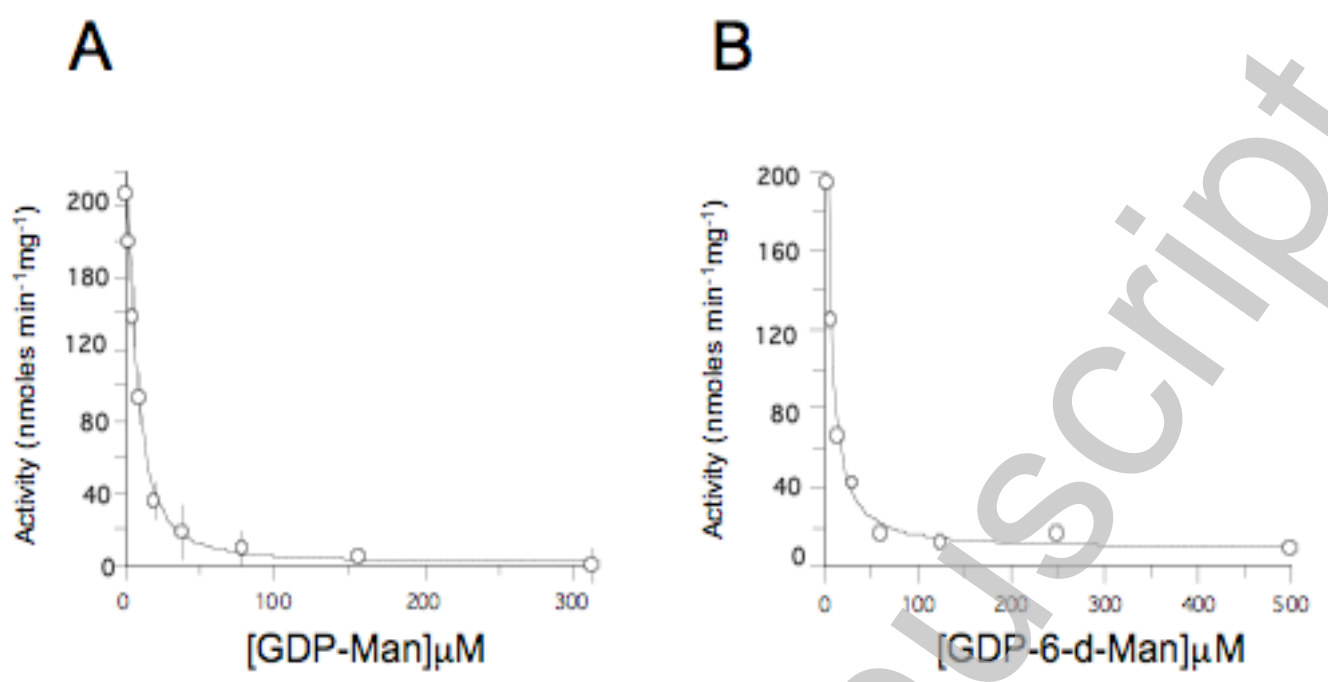

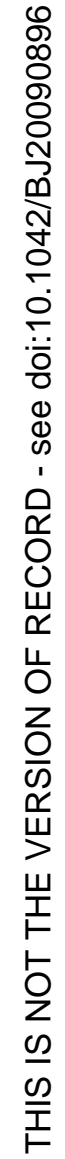

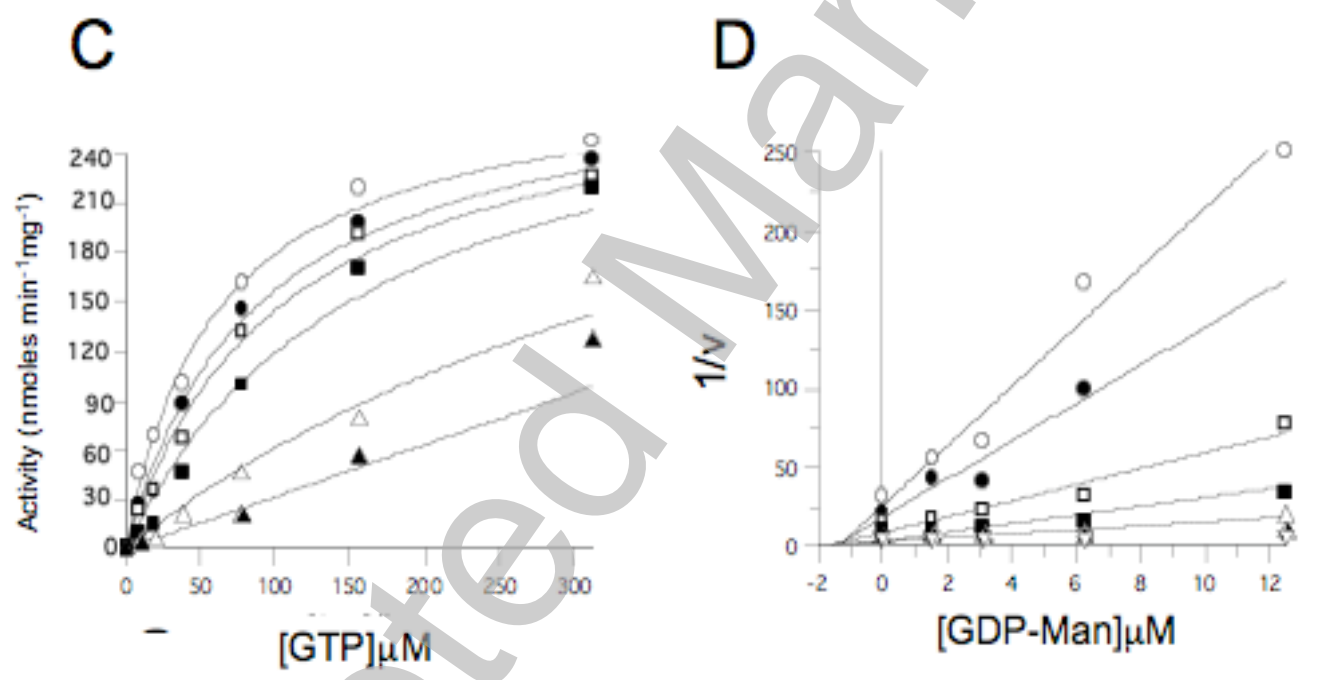


Figure 4

A
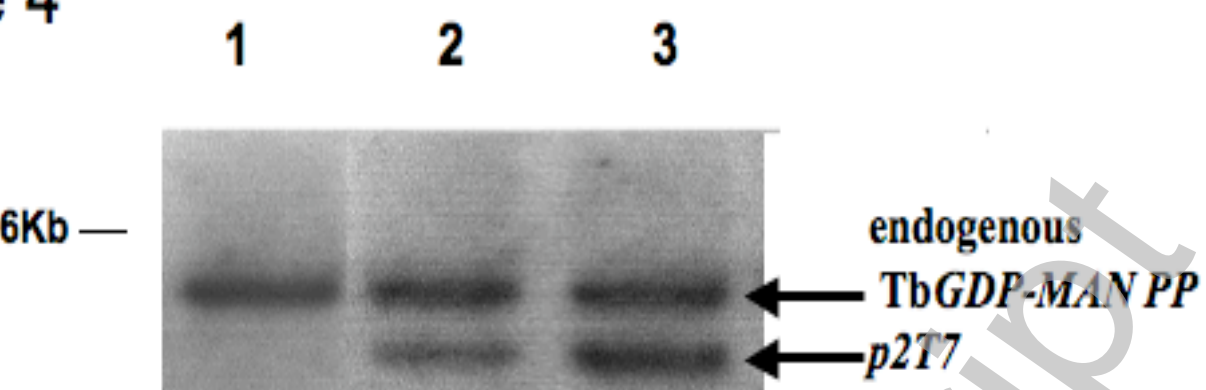

$2 \mathrm{~Kb}-$
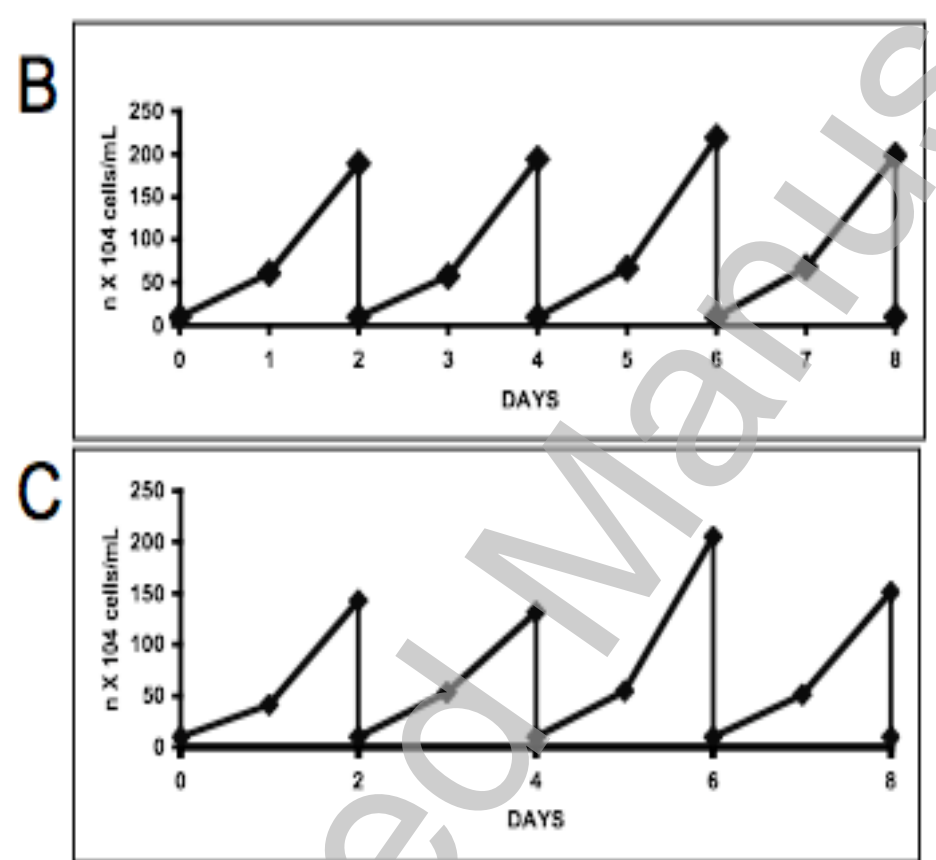

D
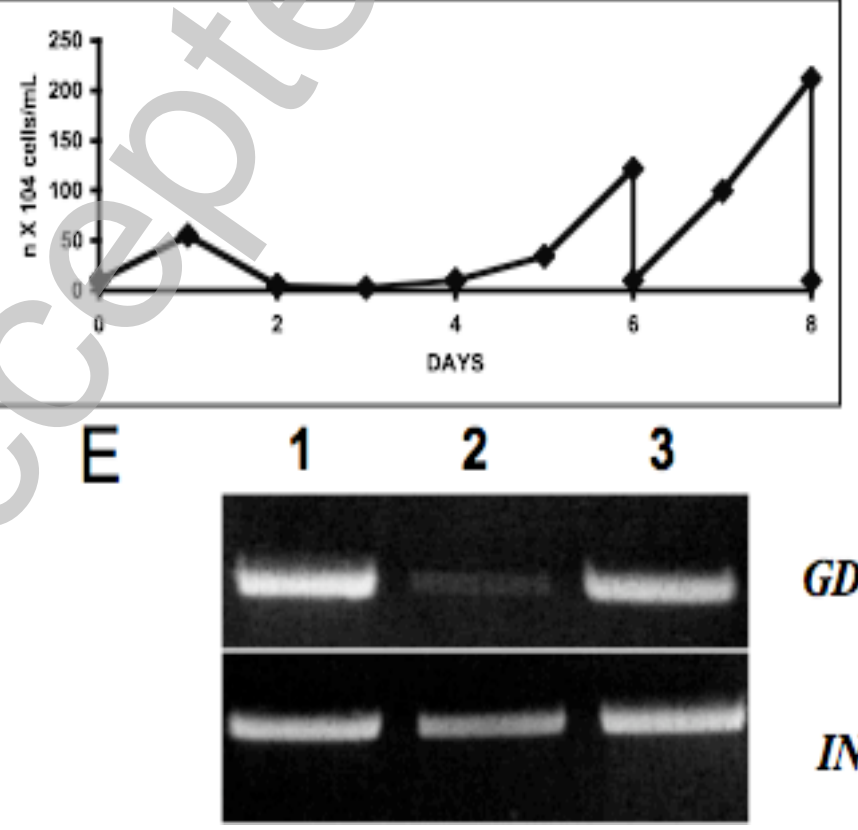

GDP-MANPP

\section{INO1}


Figure 5

A $\quad 1 \quad 2$

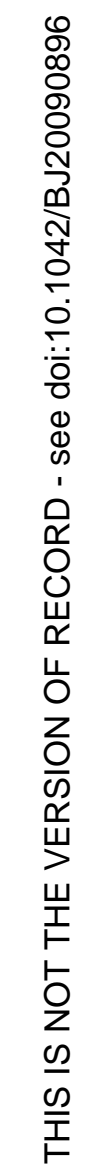
B
1
2
3
4

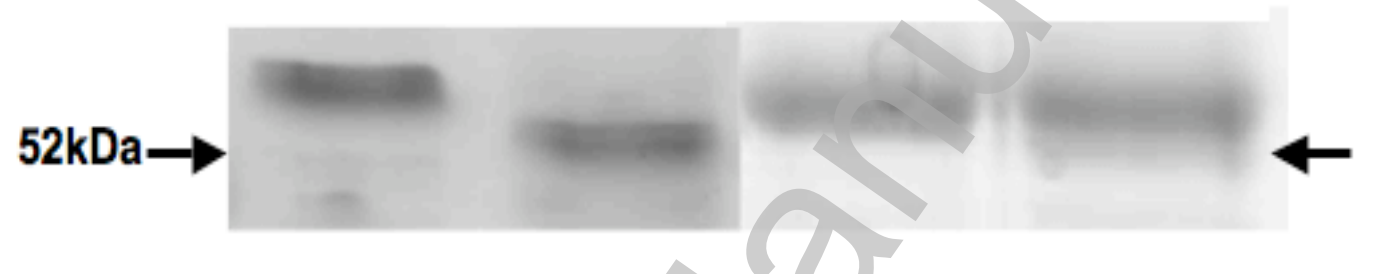

C

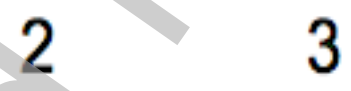

3

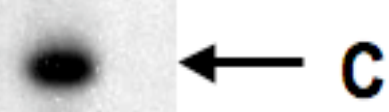

A 


\section{Figure 6}
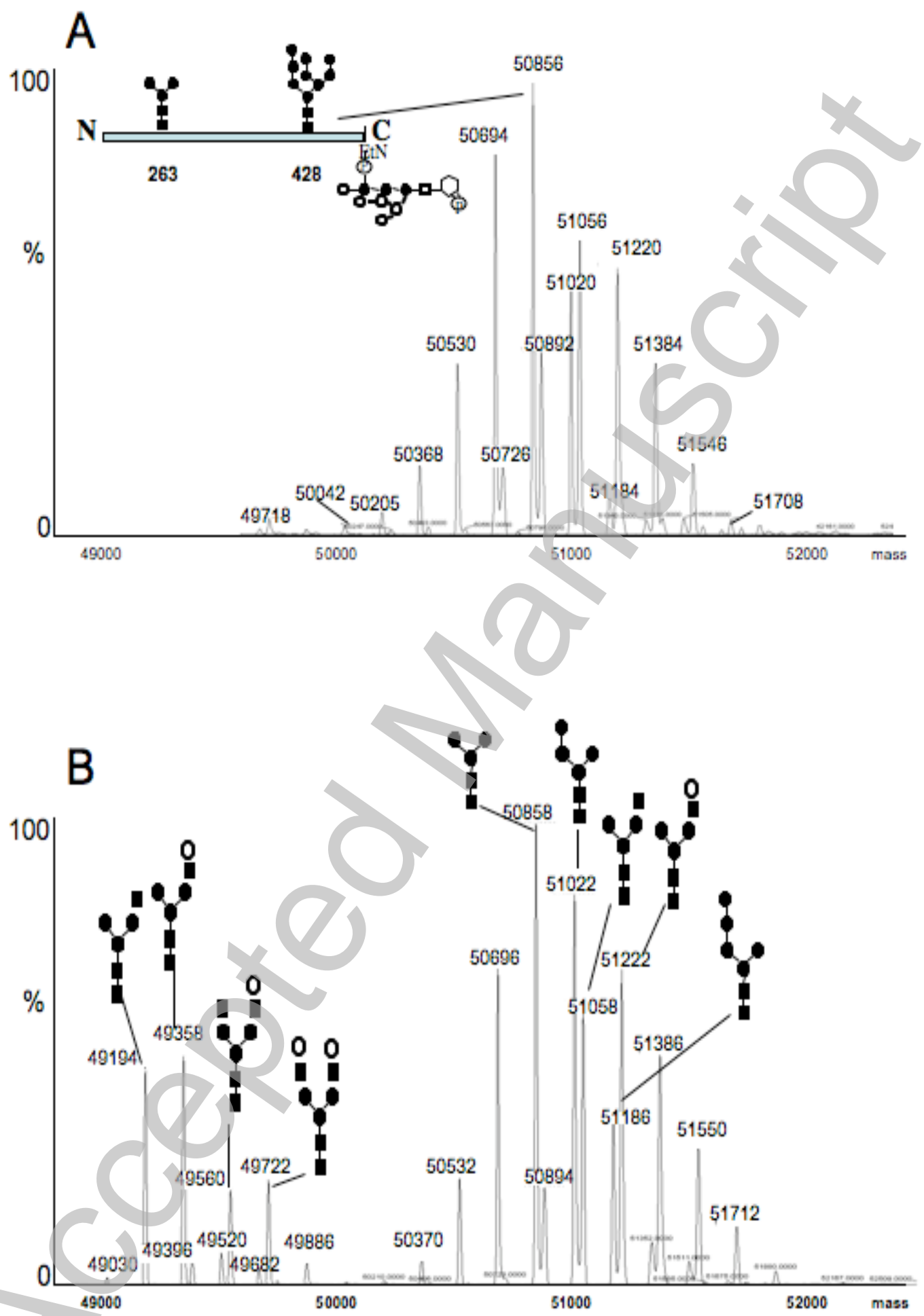


\section{Figure 7}
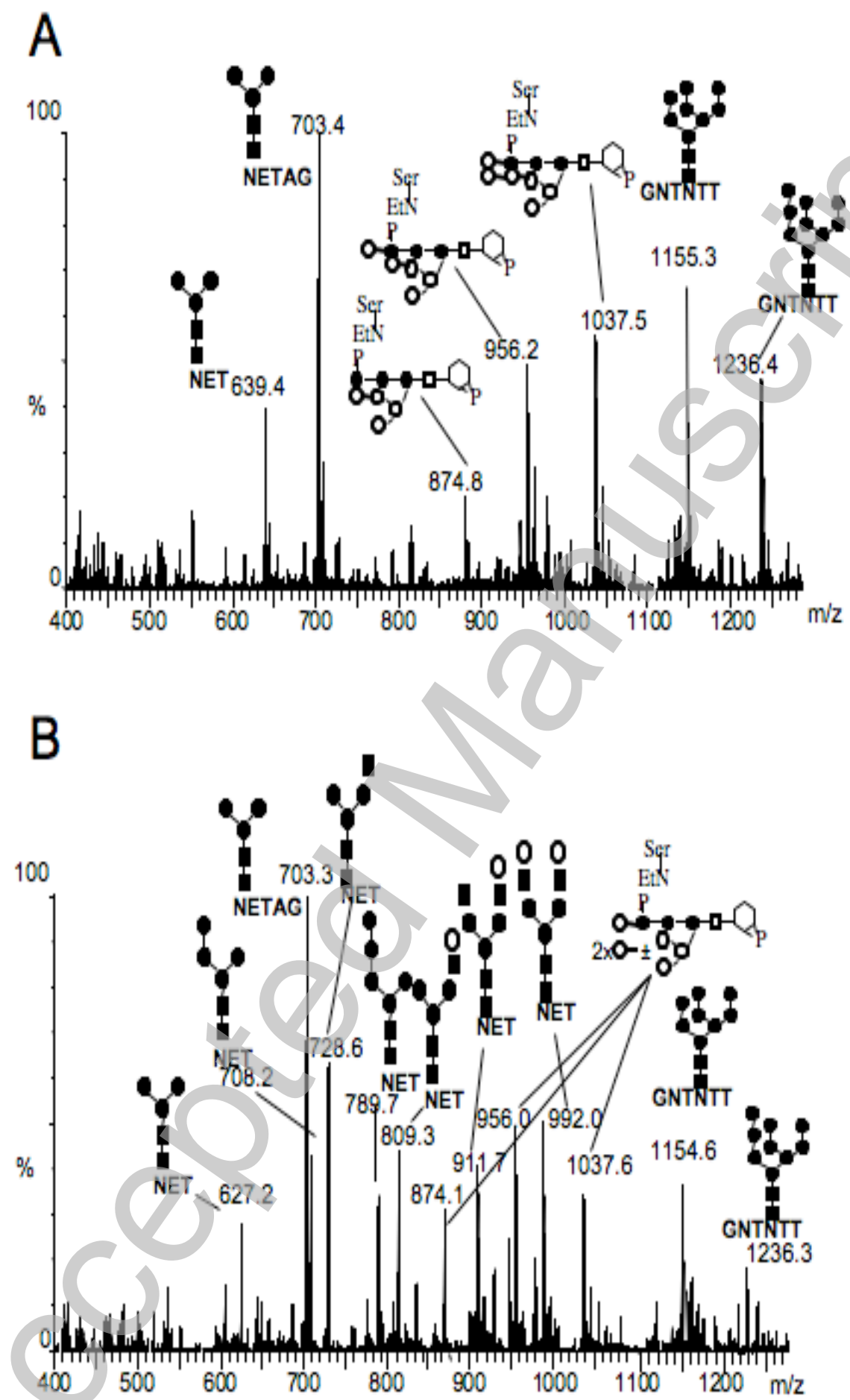